\title{
Democracy and the Reconstruction in Afghanistan
}

\author{
By Sarah A. C. Dimick B.A. (Hon) \\ A thesis submitted to the Faculty of Graduate Studies and Research \\ in partial fulfilment of the requirements for the degree of \\ Master of Arts
}
Department of Law
Carleton University
Ottawa, ON

December 2005

(C) January 06, 2006, Sarah Dimick 


$\begin{array}{ll}\begin{array}{l}\text { Library and } \\ \text { Archives Canada }\end{array} & \begin{array}{l}\text { Bibliothèque et } \\ \text { Archives Canada }\end{array} \\ \begin{array}{l}\text { Published Heritage } \\ \text { Branch }\end{array} & \begin{array}{l}\text { Direction du } \\ \text { Patrimoine de l'édition }\end{array} \\ \begin{array}{l}\text { 395 Wellington Street } \\ \text { Ottawa ON K1A 0N4 }\end{array} & \begin{array}{l}\text { 395, rue Wellington } \\ \text { Ottana ON K1A ON4 } \\ \text { Canada Oa }\end{array}\end{array}$

Your file Votre référence ISBN: 0-494-13411-9

Our file Notre référence

ISBN: 0-494-13411-9

NOTICE:

The author has granted a nonexclusive license allowing Library and Archives Canada to reproduce, publish, archive, preserve, conserve, communicate to the public by telecommunication or on the Internet, loan, distribute and sell theses worldwide, for commercial or noncommercial purposes, in microform, paper, electronic and/or any other formats.

The author retains copyright ownership and moral rights in this thesis. Neither the thesis nor substantial extracts from it may be printed or otherwise reproduced without the author's permission.
AVIS:

L'auteur a accordé une licence non exclusive permettant à la Bibliothèque et Archives Canada de reproduire, publier, archiver, sauvegarder, conserver, transmettre au public par télécommunication ou par l'Internet, prêter, distribuer et vendre des thèses partout dans le monde, à des fins commerciales ou autres, sur support microforme, papier, électronique et/ou autres formats.

L'auteur conserve la propriété du droit d'auteur et des droits moraux qui protège cette thèse. $\mathrm{Ni}$ la thèse ni des extraits substantiels de celle-ci ne doivent être imprimés ou autrement reproduits sans son autorisation.
In compliance with the Canadian

Privacy Act some supporting forms may have been removed from this thesis.

While these forms may be included in the document page count, their removal does not represent any loss of content from the thesis.
Conformément à la loi canadienne sur la protection de la vie privée, quelques formulaires secondaires ont été enlevés de cette thèse.

Bien que ces formulaires aient inclus dans la pagination, il n'y aura aucun contenu manquant. 


\begin{abstract}
$\underline{\text { Abstract }}$
This thesis seeks to examine and draw out answers to the question 'Why does the international community consistently work to instate 'democratic' governance in 'post conflict' states'? Afghanistan, one of the most current examples of internationally led reconstruction at work, provides not only a context, but also a unique set of cultural and historical challenges for the reconstruction effort. The extension of this discussion, the examination of the instatement of democracy through foreign force is the question of can democracy be legitimately imposed? I argue that the international community has played a role in the destruction of Afghanistan, most recently through a bombing campaign and subsequent military invasion beginning in October 2001. This international community ousted the only source of government, the Taliban, from the seat of power. There is therefore an obligation on the part of the international community to aid in the reconstruction of Afghanistan. Unfortunately, the international community can not do so without engaging in some kind of force or imposition, at least until a local system of governance is in place. This imposition, by the international community, often receives the critique of imperialism. The imperialism critique is unavoidable in any international reconstruction. The international community must both recognize this critique and work against it. The critique of imperialism is best tempered with an engaged and active local community that takes an ownership role in the reconstruction.
\end{abstract}




\section{Acknowledgements:}

Firstly, I would like to express my sincere thanks to my advisor, Doris Buss, who with a mix of patience and painfully precise critique guided me through this process. Thank you for all your time and effort - I really do appreciate it. Secondly I'd like to thank my second reader, Christiane Wilke, who came into the process at a late date and took it on in its entirety. Thank you for your thoughts, critique and for the great speed at which they were delivered.

My most sincere thanks and gratitude goes to my family. To my parents, David and Charmaine, thank you for your unending support. You have been the leaders of my cheering squad, my sounding board and a constant source of strength for me to borrow whenever the way seemed too tough. To Abbas, my love and partner in this life, thank you for seeing the A-Ca-Dimick in me, thank you for believing me. I could not have finished this work without your support and encouragement.

Many thanks as well go out to the countless friends and family members that have supported me throughout this process.

I would like to dedicate this work to my grandfather, Donald Dimick, a man who asked questions and listened to the answers, I'm sorry he didn't get to see me reach the end of this process but I know he would be proud. 


\section{Table of Contents}

Introduction: pages $1-3$

Chapter 1: Reconstruction Through Democracy;

Magic Ingredient or Recipe for Disaster. pages $4-22$

Chapter 2: Afghanistan:

Setting the Scene for Reconstruction pages $23-47$

Chapter 3: How Democracy is being Developed or Underdeveloped in Afghanistan .pages $48-69$

Chapter 4: Contradictions in the Internationally Led Reconstruction: the Necessary Weakness .pages $70-88$

Conclusion: ..pages 89 - 92

Sources: ..pages $93-112$ 


\section{Introduction}

This thesis was inspired by a lecture I was lucky to attend in 2003. Nelofer Pazima, journalist and filmmaker, said that "anything that is imposed is oppression and therefore should be resisted". (2003) This statement is at first glance most powerful. Its poetic simplicity gives it the illusion of pure logic and truth. Although my first impulse is to agree with her, I am quickly faced with an array of questions and doubts. Let us deal specifically with the first half of this: anything imposed is oppression. This seems to be true. The case of Afghanistan under the Taliban rule gives countless examples supporting this argument; the forced veiling and confinement of women, the banning of music, the strict rules of behaviour that discouraged even laughing in public. (Rasanayagam: 2003; 191-213) To my sensibilities, these are all oppressive impositions. What of today's impositions on Afghanistan? Is the newly developing 'democracy' any less an imposition? Even if it can be classified as a fully developed democracy, is it still a form of oppression because it has been imposed? I argue that the reconstruction of Afghanistan, as currently underway, is an imposition. The coalition forces, joined by the United Nations, NATO and other international actors are involved in imposing the 'democracy' that is being developed in Afghanistan. This new form of governance has been imposed through bombings, invasion and continued occupation. If 'democracy' is an imposition does it therefore qualify as oppression? This question forms the center of the debate.

The internationally led reconstruction of 'post conflict' societies is a growing and complicated practice. The ideals and, or norms of sovereignty and non-interference have 
long been negated in the international forum. Invasions, conquest, colonialism and intervention have a history that dates as far back as the history of human society itself. Afghanistan, the case study of this thesis, has suffered a huge amount of international involvement. This international involvement, through occupation, acts of aggression or the funding and training of local militias has been largely negative and instrumental in producing the current situation of destruction. The international community has therefore created within Afghanistan a 'legacy of interference'. (del Castillo: 2003) This legacy in turn, implies that that same international community has a responsibility to help in the reconstruction of a peaceful and stable society. (del Castillo: 2003) How should the international community aid Afghanistan and its people in the reconstruction efforts? Reconstruction of a system of governance is integral to the creation of the peaceful and stable society that the international community has a responsibility to help restore.

Democracy becomes part of the reconstruction effort. Democracy, as will be examined in this thesis, carries a particular legitimacy. Is democracy still legitimate when it is imposed? This thesis seeks to draw out the discussion on democracy, its legitimacy and the emerging human right of democracy. Specifically focusing on Afghanistan, I will address the democratization effort there, and highlight the potential for a detrimental surface-level-only 'democracy' that may be emerging there. This 'low intensity democracy' (Marks: 2000) promotes international legitimacy without succeeding to democratize Afghanistan. Finally, I will come back to the problematic nature of imposition. I argue that international aid in reconstruction is necessarily engaged in imposition. The 'legacy of interference' imposes an obligation of aid. (del Castillo; 2003) This tension is unavoidable and must be acknowledged in international 
reconstruction efforts. It should not, however, excuse the international community from its obligation of aid.

I must, at this point, make some acknowledgements of my own limitations and bias. I believe in democracy, I believe in its legitimacy and feel that when it is healthy and functioning it is a just form of government (of course, no democracy is perfect). I also acknowledge that I have limited first hand knowledge of Afghanistan. I have not had the opportunity to visit the country that is at the heart of this work, nor have I been able to discuss these issues and ideas with many Afghans. I am, therefore dependant on official governmental reports, newspaper and journal articles, as well as books, lectures and other secondary sources. 


\section{Chapter 1: Reconstruction Through Democracy;}

\section{Magic Ingredient or Recipe for Disaster}

\section{Introduction:}

The title of this chapter posits whether reconstruction through democracy is either a magic ingredient to reconstruction or a recipe for disaster. Perhaps the question is not as stark as that. There is, after all, a wealth of examples of reconstructed nations that fall somewhere in between either extreme. If democracy were to be used in reconstruction as the magic ingredient for success, without question, examination, specific tailoring or popular consensus, it would surely be in danger of producing the opposite of the stated goal. Instead of a free, fair and equal society; a haphazard mechanistic democracy can often lead to further instability, and inequality. Even more dangerously, it will be internationally viewed as legitimate while lacking in national legitimacy. $\mathrm{Be}$ it East Timor, Haiti, Afghanistan or elsewhere; democracy is thrown into the reconstruction process as if it were the magic ingredient that can guarantee a successful reconstruction. Democracy, it will be argued, is often seen by the international community as the only legitimate political system that will make countries, torn apart through violence and destruction, whole again. What needs to be interrogated is this automatic reaching for democracy.

Inherently forceful terms like legitimacy, democracy and development, circle through current discussions and debates about Afghanistan. They are powerful terms, suggesting apparent good intentions and straightforward truths. What is it that gives democracy this power of legitimacy? As international organizations, agencies and individual states such as the UN, NATO and the USA, continue to play a role in the 
reconstruction of Afghanistan, the question of legitimacy, both at a national and international level, becomes more central. Colonialism is still fresh in the minds of many, and it is important for today's global powers to differentiate their actions from those of former colonial rulers. Democracy, at least in theory, gives the Afghani people voice and control. The conundrum here is that there has been no way to collect the views of Afghanis, to find out if they themselves want democracy, and, if so, in what form. How is the will of the Afghan people to be known without some forum for deliberation and discussion such as that present in democracy? If the standard is finding what the Afghani people want, then democracy is a necessary tool. Placing the question of desire for democracy aside, the international community, with the help of Afghans, have begun to establish a working democracy in Afghanistan. It is this emerging democracy that I seek to examine.

One of the reasons why democracy is seen as a magical ingredient to successful reconstruction in 'post conflict' societies is because, as Anne Orford points out in her assessment of the military intervention of East Timor, there is a moral authority in the notion of democracy. $(2003,18)$ Moral authority and legitimacy are often based in the authority given to democratic governance by those that it rules. "If the law is properly created within the framework of the common life it legitimately commands obedience." (Held: 1996, 18) The laws in a democracy are made by the people or their chosen representatives and the presumption is that they therefore are legitimately enforceable upon the people who made them. This chapter deals with the moral authority of democracy, its claim to legitimacy and the arguments that both support these notions (of legitimacy and authority) as well as the arguments that highlight potential pitfalls. 
Democracy, it will be argued, is not necessarily the answer for projects of reconstruction. Democracy alone is not sufficient. Assumptions made about its authority, legitimacy and suitability in every situation need to be interrogated. Finally, when democracy is constructed in situations like Afghanistan, it needs to be applied substantively, not merely mechanistically.

\section{Assessing the Theoretical Debate: What is Democracy and How is it Used?}

In order to further discuss democracy's role in the reconstruction of Afghanistan or any other country recovering from conflict, a definition of democracy needs to be established. Democracy is a political concept that dates back to ancient Greece. Athens is perhaps the site of the most well known early democracy. (Held: 1996; 14) The root of the word democracy comes from the Greek words for 'people' and 'rule' and theses are the essential tenants of all various forms of democracy. (Held: 1996; 3) The current challenge is to identify a definition of democracy that is applicable today. Democracy is a term that is thrown around a lot in the political and public arena however what exactly does it mean? The definitions available span variations from 'all should govern' to 'rulers should act in the interests of the ruled'. (Held: 1996; 3) Robert Dahl points out that the term is used so often and irregularly that finding one definition is very difficult. $(2003 ; 530)$ Even if we narrow the field to democratic countries or states (excluding other organizations and groups) the discrepancies between an ideal democracy and actual democracies is so vast that it is difficult to identify a minimum standard. (Dahl: 2003; 531) Is a state democratic simply if it claims to be? Are free and open periodic elections the minimum requirement of democracy? Thomas Franck states that democracy is about 
the people's right to participate in governance. $(1999 ; 262)$ What constitutes participation? Is it simply voting or is there an insistence on the right of people to run for office; address the parliament; or even propose new legislation?

Democracy, perhaps, needs to be conceived of as a journey and not a final resting place. (Franck: 1995; 83) A spectrum of democracies exists and therefore any definition needs to be tailored to this reality. There is still the point raised earlier by Dahl that some minimum standard is needed. Therefore, in order to define democracy, this thesis will embark on the dangerous task of identifying a minimum standard. Before doing so, let us be warned of the potential risk involved in this endeavour as highlighted by Susan Marks in her work The Riddle of All Constitutions. Marks warns of ideology and the modes through which it operates. She argues that ideology often works to support relations of domination by obscuring these relations; a process she labels mystification. $(2000 ; 23)$ The operating mode of ideology that needs mentioning here is legitimation. Defining democracy through a minimum standard must not allow for the confusion of this minimum standard with the ideal. If the minimum standard is where the upcoming focus is placed it risks becoming the definition of the 'ideal' through normalization, by its repeated use and reference to it. Imagine once again a spectrum of democracy. At one end is an 'ideal democracy' (probably an unattainable one at that) and at the other end, political systems that are 'not democracy'. The minimum standard of democracy is at the furthest point of the spectrum away from the 'ideal democracy' without passing to the 'not democracy' side. It is in fact, one tiny step away from passing the invisible line between the 'ideal democracy' end of the spectrum and traveling to the 'not democracy' end. 
With this warning in mind, let us now proceed with a definition of democracy. This work employs a definition of a 'liberal representative democracy' as developed in David Held's work Democracy and the Global Order. (1995) David Held is a leading scholar in the field of democracy theory. He is, most recently, a proponent of cosmopolitan or global democracy; however in his work he discusses many other forms of democracy as well. The focus on liberal representative democracy is simply because this is currently the most commonly sought out and practiced model of democracy. (Held: 1995; 12) The reasoning behind its popularity can be attributed partly to the necessity for a political system to function; direct democracy would be an unwieldy proposition in any organization as large as a state. Held points out that modern liberal theory has sought "to justify the sovereign power of the state while at the same time justifying limits to that power". $(1995 ; 8)$ Liberal representative democracy was developed in order to achieve this goal and through the use of institutional innovations it manages to balance liberty and coercive power. (Held: 1995; 8) Today's liberal representative democracies may superficially resemble previous democracies such as those of ancient Greece but represent a radical shift in politics. The focus on universal and equal suffrage, periodic elections by secret ballot as well as the absence of exclusionary measures against certain voters, candidates or parties are all criteria for democracy that have only just been established internationally in the last half century. (Fox: 2000;69) These are twentieth century developments. (Held: 1995; 12) Held attributes the more recent developments to struggles of working class and feminist activists who worked toward establishing that the rights of citizenship should apply to every citizen equally. $(1995 ; 11)$ The distinctive 
contemporary form, liberal representative democracy as defined by Held, can be seen through what he labels a:

...cluster of rules and institutions permitting the broadest participation of the majority of citizens in the selection of representatives who alone can make political decisions, that is, decisions affecting the whole community. $(1995 ; 12)$

It is the cluster of rules that Held identifies that will provide us with our definition for a representative democracy.

This cluster includes elected government; free and fair elections in which every citizen's vote has equal weight; a suffrage which embraces all citizens irrespective of distinctions of race, religion, class, sex and so on; freedom of conscience, information and expression on all public matters broadly defined; the right of all adults to oppose their governments and stand for office; and associational autonomy - the right to form independent associations including social movements, interest groups and political parties. (Held: 1995; 12)

From this definition of a democracy a minimum standard can be developed. Although Held, as well as those he cited, presents this as the ideal form of liberal representative democracy it will serve as our minimum standard. Held's definition focuses heavily on the institutional side of democracy. Electoral rights and freedoms of expression and association are, in my opinion, one portion of the necessary criteria for democracy. Although they are important, they are not all inclusive. There are other aspects of democracy that are important. As Bastian and Luckham point out, democratic institutions and elected governments may or may not be open spaces for democratic politics; democracies may or may not be responsive to political demands. $(2003 ; 3)$ Are the inclusions of the rights to oppose government, stand for office and freedom of association in the definition by Held et al enough to ensure open spaces for political participation? Bastian and Luckham would respond that the inclusion of these rights can 
provide the powerless with some power and the underprivileged with channels of action. $(2003 ; 2)$ These authors note that this power and potential channel of action are often limited but nonetheless have "emancipatory and subversive potential". $(2003 ; 2)$

Acknowledging the potential within democracy does not provide sufficient assurances that it, as a rule, functions to provide a society with just, equal and legitimate governance. Democracy should also include some sort of accountability that rests on more than the next election's outcome. For this accountability, the rule of law must be established. The rule of law is a loaded and contested term to which theorists and scholars have devoted much attention. One of the earliest definitions of the rule of law was expressed by A. V. Dicey in the late $17^{\text {th }}$ century, today a simple search for 'rule of law' in the subject heading at the library matches over 50 books. (Cosgrove: 1980; 67) It is, however, neither the focus nor the intent of this work to engage these many and diverse volumes. The meaning of the rule of law expressed here is best defined by Hutchinson and Monahan as the 'thin' version of the rule of law. They define this as a constitutional principle of legality. $(1999 ; 125)$

It demands that government be conducted in accordance with established and performable norms; its voice remains silent or, at best whispered on the issue of substantive policies. Rule must be by law and not discretion. Also and especially, the lawmaker itself must be under the law, at least until it changes the law. (Hutchinson \& Monahan: 1999; 125)

This definition of the rule of law can exist within a non-democratic state. (Hutchinson \& Monahan: 1999 ; 126) However, it is difficult to support the opposite argument that a democratic state can exist without at least this thin form of the rule of law. It provides a system of accountability that is necessary for the functioning of a just and democratic nation. (Franck: 1999; 276; Barnes: 2001; 89-92; Prosper: 2002; 433) That those in 
power are subject equally and fully to the laws of the state empowers the state and its leaders with greater legitimacy. The legitimacy is born out of the belief that the laws, which are created by the government chosen by the people, will be enforced equally. Therefore, the government will be in a position where it is truly a subject of the people it serves rather than in a position to abuse its power and follow only the law that suites it. Hutchinson and Monahan warn of the potential mystification powers of this thin version of the rule of law. They argue that it might tend to legitimate the substantive excess of an unjust regime under the "patina of formal justice". (Hutchinson \& Monahan: 1999; 125, 126) This warning is heeded, however the rule of law as defined above working in conjunction with the minimum standard of liberal representative democracy (as defined by Held) work to legitimate each other, as Hutchinson and Monahan state.

Democracy, specifically liberal representative democracy, will be defined in this thesis as follows: A system of governance in which the government is popularly elected through free and fair elections. (Held: 1995; 12) Each citizen will have a vote with equal weight regardless of sex, class, religion. (Held: 1995; 12) It will include freedoms of consciousness, association and the right of all citizens to oppose their government and for adults to run for office. (Held: 1995; 12) This democracy is augmented by a thin version of the rule of law, meaning that all citizens are equally accountable under the law. (Hutchinson \& Monahan: $1999 ; 125$ ) To clarify, the above definition is minimalist. It is an attempt to establish the closest point to the 'not democracy' side of the spectrum without leaving the 'democracy' side.

Having established a minimum set of criteria for democracy as well as an expanded definition to include greater accountability through the rule of law, the focus must be 
shifted to the theoretical arguments surrounding democracy's role in reconstruction. Starting in the mid 1990's, alongside a rise in UN election monitoring activity, international lawyers began to speculate about the possible existence of international norms entitling individuals to democratic participation. These will be represented largely through the work of two major authors in international law. Thomas M. Franck and Gregory Fox both address the question of democracy's normative status in international law. Fox keeps his focus more cautiously restrained to the human right of political participation in the political process. Franck goes further and argues that there is an emerging international norm entitling individuals to democratic governance. I will examine the work of these two authors below in more detail.

I conclude by looking at the work of Susan Marks. Marks takes a more critical stance toward Franck's democratic governance norm. In her analysis Marks identifies the trend of 'low intensity democracy' that has the potential to garner international legitimacy while denying democratic rights nationally. My objective is to provide a basis for the examination of international reconstruction efforts that so consistently seek to instate democracy in 'post conflict' societies.

Franck and Marks work through the issues arising from the pervasive popularity of democracy in the international arena. They also focus on the internationally driven process of establishing new democracies or re-establishing democracies with connected but very different outlooks. Franck's optimistic outlook on both the inherent legitimacy and rapid growth of democracy throughout the world is contrasted with Marks' warnings on the dangers of reconstruction through democracy. There are many other authors who contribute valuable work to the question of the role of democracy in reconstruction and 
although some of their thoughts and arguments will be highlighted, this section will focus on the different arguments of Franck and Marks and examine what their ideas can lend to each other in order to create an even more realistic yet positive approach to the subject.

These three authors, particularly Franck, are leaders in their field of international legal theory. Fox's work is closely tied to the subject of the norm of democratic governance as established by Franck, and Marks' work in many ways is a response to Franck. I have selected their work to represent various perspectives on both the norm of democratic governance and the role of democracy in reconstruction. I feel that they are the strongest among authors I have read. The combination of the authors also works to provide a balanced look at democracy, in establishing a right or norm to democracy and the effects of different types of democracies in developing, or reconstructing societies.

Fox and Franck argue, along similar lines, that there is an inherent right to political participation established in international law. Fox, as will be shown, comes to this conclusion through slightly different means than Franck and is slightly more critical of the process of democracy. According to Fox, international law understands democracy in a narrow and process oriented way. $(2000 ; 49)$ He points out the limiting nature this understanding of democracy has. Fox argues that in the eyes of international law, it is the aspect of popular consent through the electoral process that defines democracy. (2000; 49) Simply stated, democracy is defined by the identification of procedures through which democracies function. (Fox: 2000; 49) This criticism is a common one that is echoed by Marks (although more forcefully).

In his chapter entitled "The Right to Political Participation in International Law," Fox conducts a detailed examination of international treaty laws and case examples. 
$(2000 ; 48-90)$ He traces the emergence of internationally recognized participatory rights beginning with the 1948 Universal Declaration of Human Rights. (2000; 52) He focuses particularly on the evolution of participatory rights. In his concluding remarks, Fox argues that "parties to the major human rights conventions have created an international law of participatory rights". $(2000 ; 90)$ According to Fox, these rights include not only electoral rights but also the right to non discrimination and the right to participate in government $(2000 ; 53)$ He summarizes these rights as established through treaties, therefore creating established norms about free, fair and legally sufficient elections. These elections must include the following four elements in order to qualify as adhering to the established norm: universal and equal suffrage; secret ballot; elections at reasonable and periodic intervals and the absence of discrimination against voters, candidates or parties. $(2000 ; 69)$

After examining various international treaties, Fox turns to acts of international election monitoring as an enforcement mechanism for participatory rights. $\mathrm{He}$ is specifically referring to the United Nations elections monitoring and assistance provided in developing countries. His argument is that the practices of the United Nations in these situations have facilitated the fulfillment of the treaty-based participatory rights. (2000; 70) Fox points out that in recent years the United Nations has implicitly endorsed participatory rights through elections monitoring and assistance as well as situated themselves in the role of enforcer. (2000; 70) It could be added, and will be discussed below, that the United Nations' role goes beyond endorsing participatory rights to include legitimizing force of these new democracies. 
Fox makes his point about the role of the United Nations, much in the vein of Franck's work as will be shown below, by citing the increasing UN involvement in electoral assistance in the post colonial era. The 1989 case of Nicaragua, for instance, was the first UN monitoring in an independent state. The UN mission was there by invitation for the purpose of verifying a free, equitable and proper election. $(2000 ; 75,76)$ This was just the first in a long line of electoral assistance missions. The 1990 Haiti mission is yet another example. $(2000 ; 78-80)$ Fox argues that the international community has come to act as an ombudsman; making sure the state will act in interest of its citizens. $(2000 ; 90)$

Fox has developed an argument that there exists a 'treaty based' and 'state-practiced backed' international right of citizens to political participation. Although Fox discusses these rights of citizens to political participation, he refrains from labelling the political system that allows this basic political participation democratic. In his writing Fox avoids both the terms 'democracy' and 'self determination'. In his discussion of the treaty-based right of political participation, Fox argues that the criteria developed for free and fair elections are less than comprehensive. He particularly points out that although there are specific elements established through treaties such as universal and equal suffrage that ensure the democratic process, no requirement is made for party pluralism. $(2000 ; 69)$ Fox's choice to abstain from using both the terms 'democracy' and 'self determination', and his critique in of the lacking criterion in the treaty based right of political participation are telling signs. When understood in conjunction with his earlier critique of the treaty based norm as overly focused on procedure, it is evident that although he 
recognizes the established right to political participation is part of democracy, it is not definitive of it. Therefore he states:

That receipt of an electoral mandate bestows legitimacy upon governments, that genuine choice in an election requires multiple political parties, that incumbent regimes can not monopolize the mass media during a campaign and that the other elements of fair elections must be provided, all seem to flow inevitably from the treaties announcing a commitment to representative government. $(2000 ; 89)$

Like Fox, both Marks and Franck recognize the fact that liberal democracies are rapidly spreading throughout the world and within the last few decades the numbers of democratic states seem to be growing exponentially. (Fox: 2000; 89; Marks: 2000; 3037; Franck: 1995; 85) This trend is the focus of many other scholars as well. Francis Fukuyama, for instance, feels that western liberal democracy has emerged as the final form of human government and that an international peace will emerge out of the 'specific nature of democratic legitimacy'. $(1989 ; 11)$

Franck attributes this trend, the quickening spread of democracy, to the sense of fairness that is rooted in democracy. $(1995 ; 85)$ To make his argument, that there is an emerging international human right to democratic governance, Frank points out the 130 plus countries that are legally committed to democracy (as of 1994). He notes that most of these countries had joined this group of democratic states in the last decade alone. According to Franck, many of these countries want or need to be seen as complying with international standards for free and fair elections. $(1995 ; 85,86)$ Franck argues that there is a norm of democratic government that is emerging under international law, (the democratic norm thesis). $(1995 ; 137)$ He bases this emerging right to democracy in both theory and practice and sees it as the final phase in a movement that has been developing since the emergence of the right to self-determination after World War 1. (1995; 91-92) 
According to him, the legitimacy of governments would be decided by international criteria that would stipulate democracy, such as the international treaties mentioned above by Fox, therefore democratic governance would be established as a human right. $(1995 ; 138)$

Franck asserts that in western liberal democracies the process of government is subjected to rules that are validated by citizens; therefore the system is viewed as having legitimacy. $(1995 ; 89)$ He then points to the capacity of the international system to lend legitimacy to governments of states that have not yet established the institutional process of democratic governance. $(1995 ; 90)$ Franck ultimately argues that the emerging concept of democratic entitlement enjoys a high level of legitimacy and promises a new global political culture. $(1995 ; 138)$ He posits that the international system is moving to include clearly defined democratic entitlement; that national governance will not only seek but need international validation. $(1995 ; 139)$ According to Franck this will ensure democratic governance. He states: "The task is to perfect that which has so wondrously begun." $(1995 ; 139)$

Franck's arguments appear to be shared by those undertaking international reconstruction projects. The international community has applied the ideas of the democratic entitlement and carried out a process aimed at legitimating these newly founded democracies in the eyes of the international community as well as the respective national community. Franck's democratic norm thesis can be supported by the examples of international involvement in East Timor, Afghanistan, and Iraq. The international community consistently instates a reconstruction plan that has the goal of developing a democratic government, or at a minimum the institutions necessary for an emerging 
democracy, are in place through the reconstruction project. (Falk: 2004; 28-29) Democracy is the 'magic ingredient' thrown into each nation undergoing an internationally led reconstruction regardless of culture, religion and location.

Democracy not only gives the newly formed or reformed government a greater sense of legitimacy. The pendulum swings both ways, legitimacy is also attributed to the intervening countries who publicly work towards the spread of democracy. The western world, which comprises the bulk of the states involved with intervention and reconstruction, gains legitimacy for its actions of intervention and reconstruction in what in many cases were sovereign states by working to implement democracy. The West, however, is exporting its values through the promotion of democracy worldwide.

Susan Marks, in her book The Riddle of all Constitutions, explores Franck's argument for the emerging right of democratic governance. (2000) She argues that for a very large portion of the world there is no other political tradition at work that can feasibly challenge democracy. $(2000 ; 34)$ From Franck's arguments she points to the push for periodic and genuine elections as the essential first step on a democracy. According to Marks, this is largely because elections are more easily monitored than long term investments. (Marks: 2000; 40) Marks subjects Franck's democratic norm thesis to scrutiny, highlighting the tension between west and non-west that this norm creates. $(2000 ; 46)$ She asserts that it is important not to overstate the liberal revolution. Many nations do not practice democracy and do not aspire to do so. $(2000 ; 46)$ There is a problem when peace and democracy are brokered through intervention and ultimately through victory. "I think the sceptics are right to warn that the risk of neo-imperialism looms large" (Marks: 2000; 1) 
Marks moves the discussion of the democratic norm thesis forward by examining a trend she identified in the international community of the promotion of what she labels 'low intensity democracy' (LID). (2000; 50-75) She identifies LID with the conception of formality, such as the emphasis on elections. $(2000 ; 52-53)$ She asserts that there is an undemanding set of standards dealing with other objectives such as human rights and the rule of law. $(2000 ; 52-53)$ According to Marks, the United States has led the way in promoting LID. It is closely linked to stabilizing the existing positions in the global system. $(2000 ; 56)$

The identification of the trend of LID is not unique to Marks' work. Barry Gills, Joel Rocamora and Richard Wilson have identified the same trend (they label it cosmetic democracy) and argue that although it may work in the short term, it is fragile and ineffective, lacking the ability to address social, political and economic problems in the long term. (Gills et al: 1993; 8) They too, site the problematic nature of the fixation of LID on the electoral process. (Gills et al: 1993; 9) Anne Orford also takes issue with instances of self-determination defined as the right to a process by virtue of which all people freely determine their political status; she criticizes this as mechanistic and minimalist. (Orford: 2003; 144) LIDs or cosmetic democracies are legitimized in part by elections which are seen as the essential first step. (Marks: 2000; 60-61) The concentration on voting itself helps obscure structural inequalities, therefore the electoral fixation is used to obscure the inequality that exists in the situation. (Marks: 2000; 63-64) Marks argues that there is a two track approach to democracy in the international arena; one sophisticated track for developed societies and a less developed track for others. $(2000 ; 67-74)$ 
If Marks' assertion about low intensity democracy is correct, if it is a situation "where democracy differs little from authoritarian rule but enjoys significantly greater legitimacy" $(2000 ; 61)$ then the international community is facing a significant dilemma. Arguments such as that put forward by Gills et al that "cosmetic democratization' is legitimated such that democracy is in danger of serving as a euphemism for sophisticated modern forms of neo-authoritarianism". $(1993 ; 7)$ and Marks' own warning of neoimperialism as highlighted earlier are not only scathing but also potentially accurate. The truth may be, as Marks suggests, that moves to support democratic initiatives may actually curb democratic aspirations. $(2000 ; 53)$ This occurs through the failure of a LID to generate substantive democratic elements, instead LID resists any redistribution of power. (Marks: 2000; 55) If this is the case, then reconstruction efforts in countries such as Afghanistan are in danger of implementing low intensity democracies that are fragile and ill-equipped to deal with the myriad of problems facing 'post-conflict' states. Also, the link between internationally-led reconstruction and low intensity democracies clearly shows a continuation of the imperial legacy as I argue in Chapter 4.

Marks is adamant in her response to these dismal conclusions. She states "I do not accept the conclusion that the attempt to secure explicit international legal support for democratic agendas should be dropped". (Marks: 2000; 1) Rather she argues for a full intensity democracy, one that more closely represents our ideal definition of democracy as described earlier. Further she advocates for the eventual "creation of a democratic community that both involves and cuts across nation states", a world in which citizens have a voice, input and political representation. $(2000 ; 84)$ Marks' ultimate goal turns to the arena of cosmopolitan democracy and global governance; although it is an important 
part of Marks' work, and many other scholars, it is not one that this work will have opportunity to deal with as it is outside the scope.

\section{Conclusion:}

Democratic theory is an enormous field that expands far beyond the authors reviewed in this work. These authors, however, are the forerunners in the debates over democratic entitlement, and the legitimization of democracies in international law. Afghanistan is a newly developing democratic state, emerging out of a quarter century of violence and destruction. The international community, following the American led attacks of October 2001, has stepped into the role of guide and guardian on the road to Afghanistan's democratic reconstruction. The legitimacy of the invasion itself is subject to question. The focus here is not on whether the international community had the right to meddle in the affairs of a sovereign state. The simple fact is that the international community is involved, and portions of it have been involved long before the American led invasion of 2001. And by being so involved, there is a moral responsibility to aid Afghanistan in its attempts to construct a stable, safe and just country for the first time in a generation or, as some historians may argue, for the first time ever.

Authors like Franck and Marks will help in assessing this process of internationally led reconstruction. Held produced many definitions of democracy, however, his definition of a liberal representative democracy as augmented by Hutchinson and Monahan's thin version of the rule of law provides a yardstick with which to measure the emerging democracy in Afghanistan. Fox and Franck's arguments for inclusive and substantive democracy will provide insight throughout this assessment 
of the developments towards democracy in Afghanistan and the international community's role in the reconstruction efforts there. Marks' warnings about the problems of legitimating a 'cosmetic' or 'low intensity' democracy will highlight threats to the fulfillment of democratic realization in Afghanistan. There is a challenge of the realization of substantive democracies in each state that proclaims itself a democracy. Low intensity democracy is a threat to all 'post conflict' societies working to develop democratically, especially those the international community has a hand in setting up in which the focus is heavily places on the electoral process. This challenge is not insurmountable.

The international community at work in reconstruction efforts and elsewhere has to be clear in the goals it states; whether the development of and electoral process or a full democracy. It is possible that the institutions alone will provide a forum for the full development of substantive democracy. The actors involved in the national politics of a 'post conflict' society may in fact be able to 'act their way' towards democratic development. They may be able to use the institutions of democracy to establish substantive elements of democracy such as freedom of association and speech. This is a possibility. There is also a possibility that such a democracy will not develop but instead the system of governance will be fragile and unable to address the needs of the population. The establishment of formal democratic institutions can not, therefore, be equated with the establishment of democracy. 


\section{Chapter Two:}

\section{Afghanistan: Setting the Scene for Reconstruction}

\section{Introduction:}

Democracy has been the tool of governance used in many recent cases of internationally led reconstruction. Chapter one examined the debated surrounding the emergence of democratic norm in international law which likely impact the promotion of democracy in 'post conflict' reconstruction. This process, the internationally led reconstruction of 'post conflict' societies and the goal of establishing democracies in these cases is exemplified in the case of Afghanistan. In the wake of the American led intervention into Afghanistan in the fall of 2001 the international community, predominantly the UN, NATO and their member states, attempted to restore order and stability, among other things, through the development of a democracy. Afghanistan has both a fractious history diverse and collection of cultures. The culture, politics and power structures found in post 2001 intervention Afghanistan have evolved throughout Afghan history. Of course a country is influenced by its history, it is because of the present day influence of historical incidences this chapter will attempt to address a few key trends of Afghan history that emerge as particularly problematic in the current democratization goals.

Afghanistan has undergone many drastic changes in the past four years. The country is currently engaged in a complex process of reconstruction, at all levels of civil society and infrastructure, from the formation of political associations to the building of 
roads, schools and hospitals. After enduring a quarter century of violent instability, from the Soviet invasion of 1979 to the rule of the Taliban, Afghanistan has much to rebuild and reconstruct. Foremost in this process is the reconstruction of governance, the construction of a democracy. This chapter will focus on how Afghanistan, a war torn country, rebuilds and in doing so how it attempts to build a stable and functioning democracy for the first time.

\section{History Condensed: Key Themes in Afghan History:}

History can not be imagined as an abstract. It influences, shades and alters the way in which we act and react in this world. This is as true in the case of individuals and their personal history as it is for communities and their collected histories. History is integrally connected to the present and therefore the future. For this reason it can not be ignored, separated or split away from the present. The history of Afghanistan must be understood and acknowledged in order for an informed examination of the present reconstruction process. As a secondary caution about history; history is often comprised of as much fact as fiction. Ever variable depending on its teller, history alters in the telling. The history of Afghanistan is no different, therefore I would like, once again, to acknowledge my limitations. I have been dependant on the scholarly work of others that has formed the image of Afghanistan I will present below, I have attempted to use many different reliable sources in order to provide as balanced a picture as possible.

Chris Johnson and Jolyon Leslie describe two aspects of recent Afghan history that present a challenge to the current reconstruction project. The first of these is a fierce 
resistance on the part of Afghans to "foreign interference and the imposition of values or ideologies that are perceived to be alien." $(2002 ; 862)$ According to them, this is

a thread that runs through British imperial support for Amir Abdur Rahman Khan during the 1880 s, efforts at reform by Amanullah during the 1920 s and to attempts in the late 1970s by the People's Democratic Party of Afghanistan to create a socialist revolution in a largely feudal society. $(2002 ; 862)$

The second trend is a political fragmentation across the country. $(2002 ; 862)$ The history of Afghanistan can not possibly be condensed into a few short pages. Instead I have compiled a small portion of Afghan history from as many available sources as possible. In doing so my goal is to highlight these trends that Johnson and Leslie have identified as well as give a more detailed examination of the past quarter century of Afghan history.

The first trend, the resistance to foreign interference and the imposition of values that are perceived to be alien, is exemplified many different times throughout Afghan history. (Johnson \& Leslie: 2002; 862) It is possible that this resistance is in part due to the 'ebb and flow' of conquest that Fosco Marani describes as a significant part of Afghan history as cited in Schofield. $(2003 ; 23)$ The first documented conquest of the area that is known today as Afghanistan occurred in the sixth century BCE with Darius the Great who conquered Kabul and the valley of Peshawar thus incorporating the area into the Persian empire. (Fletcher: 1965; 28) Only one on a long list of conquests, this early one is exemplary of the trend that would continue throughout the centuries.

The Afghan resistance and opposition to foreign invasion are clear in the First Anglo Afghan War, which lasted from 1839-1842. (Ewans: 2002; 70, Rasanayagam: 2003; xvii) In this war, the British not only invaded and imposed a change in governance, reinstating Shah Shuja, they also brought many practices, such as alcohol and gambling, 
that were offensive to Afghans. (Klass: 1990; 36) The Afghans, through their military advances, kept the British military involved in the country much longer than anticipated. The costly and surprising nature of the mission was compounded by rebel attacks and an eventual defeat of British forces that had, in their overconfidence, left themselves exposed. (Fletcher: 1966; 96, Roberts: 2003; 8) This war, also referred to as Auckland's Folly, is only one example of Afghan resistance.

Johnson and Leslie point out that the resistance is largely to values that appear to be both imposed and alien. The reforms attempted by Amir Amanulla Kahn who ruled Afghanistan in the 1920 's were defiantly perceived as alien to the greater public. Afghanistan of the 1920's was largely rural and predominantly organized by feudal relationships. (Roberts: 2003; 39) Amanulla was convinced that rapid development and liberalization was an absolute necessity for Afghanistan. (Roberts: 2003; 43) Amir Amanulla Kahn was sympathetic to state reforms in Turkey and began to implement similar reforms in Afghanistan. He banned purdah (the veiling of women and general separation of the sexes) and pushed other reforms such as opening schools for girls and universities. (Anwar: 1998; 20, Roberts: 2003; 43) He also made other legal reforms influencing gender relations such as limiting child marriage and altering female inheritance. (Roberts: 2003; 43) The pervasiveness of his reforms essentially resulted in "assaulting the entirety of the established social norms". (Roberts: 2003; 44) "Amanulla alienated every segment of the Afghan nation, save a few Westernized inhabitants of the cities." (Roberts: 2003; 44) Amanulla's forced alterations created outrage in Afghanistan and sparked multiple uprisings. (Roberts: 2003; 45) The unwillingness of the general population to change provided both the motivation and opportunity for his political 
overthrow. (Anwar: 1998; 22, Roberts: 2003; 52, Saikil: 2004; 99) Auckland's Folly and Amanulla's forced alterations are only two examples of the history of fierce resistance within Afghanistan to "foreign interference and the imposition of values or ideologies that are perceived to be alien." $(2002 ; 862)$

The second trend identified by Johnson and Leslie is the long experienced political fragmentation across the Afghanistan. $(2002 ; 862)$ The political fragmentation can be largely attributed to the cultural differences among the people now known as Afghans. For instance Afghanistan is a multilingual country, the majority of Afghans speak either Dari or Pashtu. (Ghani: 2005) The population can be divided along ethnic lines of Pashtun, Tajik, Hazara, Uzbek, Turkmen, Aimaq, Baluch, Nuristani and Kizilbash. (US Bureau of South Asian Affairs: 2005) The population can also be divided along religious lines with an $80 \%$ majority of Afghans Sunni Muslim and 19\% Shia Muslim. (US Bureau of South Asian Affairs: 2005) Ethnic and religious reasons are not solely responsible for fractionalization among the country. There has long been a lack of a nationalism working to unify the country. (Hyman: 2002; 299) In fact, it can be argued that the one nation-building force within Afghanistan is the resistance to foreign occupation and intervention.

The reality of a fractionalized society in Afghanistan combined with the lack of some authoritative national force has meant that Afghans depend first and foremost on their local leadership. One government, in particular, did work to create a sense of Afghan nationalism. Although his rule was short, Nadir Khan ruled from 1929 until his death in 1933, he provided a foundation of stability that Afghanistan desperately needed. (Ewans: 2002; 104) He was a proponent of nationalism. Nadir Khan wanted reform but 
at a slower and more manageable pace than Amanulla. Nadir declared the goals of rebuilding Afghanistan and "to rule according to the Shariat of Muhammad and the fundamental rules of the country (and to strive) for the protection of the glorious religion of Islam, the independence of Afghanistan and the rights of the nation and for the defence, progress and prosperity of the country." (Saikal: 2004; 99) His balancing act consisted of instituting enough social reforms to appease reformers without moving so quickly as to arouse conservatives. (Magnus \& Naby: 1998; 44) The reforms and nationalism that Nadir Khan initiated in Afghanistan could potentially serve as a template for the current goals of nation building and reconstruction in Afghanistan.

The above examples of Afghan history are far from all-encompassing. They do, however, serve to illuminate the trends of resistance and fractionalization as described by Johnson and Leslie. Foreign intervention and occupation reached a new level in Afghanistan at the outset of the Soviet invasion. This occupation was followed by the outbreak of civil war and the rise of the most pervasive national movement in recorded Afghan history, the Taliban. I will now turn to examine the events from 1979 to 2001 in Afghanistan to more clearly provide a context for the current reconstruction efforts in the country.

Soviet Invasion and the Rise of the Taliban:

Between the mid 1950s and 1970s the Soviet Union became increasingly involved in Afghanistan. Long interested in Afghanistan, the Soviet Union saw a great opportunity in this relationship as it allowed for some counterbalance to the American influence in Iran, Pakistan and Turkey. (Saikal: 2004; 122) Within the first decade of this 
periode most of the Afghan army was Soviet trained and armed. (Saikal: 2004; 123) By the end of the 1970s Afghanistan was greatly changed, Soviet influence had penetrated every aspect of Afghan society, building roads and highway systems, gaining control over resource development and gaining influence within the education system. (Klass: 1990; 5) This era, from mid 1950's to mid 1970's, became one of major change in Afghanistan, funding came not only from Soviet but also American sources as the American interest had been perked by the increase in Soviet involvement. (Rasanayagam: 2003; 34) Then President Daoud succeeded in establishing a growing economic system and infrastructure. (Saikal: 2004; 131) In addition to the betterment of the country, there was a simultaneous growth in the field of education, including the education of women. (Saikal: 2004; 131)

This liberalization was also occurring at the political level. An opposition coalition called the Peoples Democratic Party of Afghanistan (PDPA) formed, and, in April 1978, carried out a coup. (Roberts: 2003; 214) The PDPA didn't have a firm control over the populace and repeatedly requested aid from the Soviet Union. Eventually the Soviet Union agreed to send in troops in order to shore up PDPA power. Unfortunately for the PDPA, this was also a coup as the Soviets instated a different government upon their arrival in December of 1979. (Saikal: 2004; 191-194)

During the Soviet occupation, Islamist movements in and around Afghanistan began to gain popularity and power as well as appeal to the occupied nation. (Ewans: 2002; 154, Pazira: 2005) The movement took on distinct aspects of "Islamic Jihad" in the 1980's and the Russians became increasingly worried that Islamic sentiments could destabilize policies in much of Central Asia. (Ferguson; 2004) The Islamic Jihad 
movement was comprised of various different groups, formed along tribal or religious lines. These rebel groups came to be known as mujahidin and were often composed largely of refugees and found funding in Pakistan and Iran (they were comprised of Sunni and Hazara Shia respectively). (Ewans: 2002; 155) As refugees fled to Pakistan and Iran the mujahidin militias there received fresh new recruits. (Ewans: 2002;160) Due to the activity of these 'rebel groups', more commonly thought of as 'freedom fighters' among the Afghans, the Soviet aim of establishing a puppet regime and withdrawing its army was made impossible. As a result, continued Soviet military presence was necessary. (Ewans: 2002; 159) Although the Islamist groups managed to create great hardship for the Soviet cause, they were never able to unify as a single Afghan force and therefore were unable to achieve great military success.

The mujahidin did manage to wear the Soviet forces to the point where the president of the Soviet Union, President Gorbachav, who had been in power since 1985, described Afghanistan as a 'bleeding wound'. He recognized that it would never fully be under Soviet control and therefore, he conceded to the 1988 Geneva Accords. (Ferguson: 2004) This international agreement contained documents that outlined prohibitions of any increased military aid, non-intervention clauses for both the United States and Soviet Union in the internal affairs of Afghanistan and a timetable that ensured full Soviet withdrawal. (Rasanayagam: 2003; 121) This international agreement managed to get the Soviet Union out of Afghanistan. Afghans were neither party nor participant of the meetings that led to the creation of the accord. (Rasanayagam: 2003; 122)

The final Afghan civilian death toll from the Soviet War or occupation is estimated to be over one million. This figure does not begin to address the millions of 
internally displaced persons and refugees caused by the war. (Ewans: 2002; 172, Schofield: 2003; 326) A 1986 UNHCR report labelled the war and its aftermath as a "situation approaching genocide" and cited extreme economic disruption, towns completely destroyed and a countryside littered with landmines. (Ewans: 2002; 172) The Afghan government that was installed through the Geneva Accords inherited vast weapon stores from the Soviets. The Soviets also continued to fund this government and supplied arms, food and fuel. (Ewans: 2002; 174) This aid continued until 1992. (Ewans: 2002; 180) The government that no one expected to last more than a few months after the Soviets withdrew survived almost three years of internal conflict and uprising.

In April 1992, the UN once again brokered a peace agreement in Afghanistan, this time with a 15 member council of Afghan Mujahidin (self proclaimed freedom fighters). The agreement handed over control of Afghanistan to this group of mujahidin. (Ewans: 2002; 181, Saikal: 2004; 209) This coalition of various armed groups was unable to agree on anything. Clashes over tribal, ethnic, religious and personal differences added to the difficulty of stabilizing Afghanistan. (Saikal: 2004; 210, 211) In addition to internal conflict between different mujahidin groups there was added tension from outside Afghanistan. Each mujahidin group had ties to neighbouring countries, such as Pakistan and Iran, where they had originally been founded. (Ewans: 2002; 182)

It was at this instance of chaos that the Taliban came to the forefront of Afghan current affairs. Pakistan's then Minister of the Interior, Naseerullah Kahn Banar, has been described as the 'godfather of the Taliban'. In 1994 he recruited, trained and armed a number of students recruited from the Afghan refugee population in Pakistan, many of whom lived in camps close to the Afghanistan/Pakistan border in the Peshawar valley, to 
provide protection to a Pakistani convoy traveling through Afghanistan. (Saikal: 2004; 221) It is from this original group that the Taliban grew into a powerful, trained, well funded militia. They brought with them hopes of stability as they promised to clean up corruption and end the opium trade. (Schofield: 2003; 335) Their strength and training gave them a unity and force that other mujahidin groups lacked. The Taliban was the first group in Afghanistan in years that had the strength to rule effectively. They were an Afghan group, using the force of the faith in Islam and the training they received in Pakistan to unify and rule the country. Afghans saw hope in them and in the four months between November of 1994 and February of 1995 the Taliban ranks grew from 800 to 25,000. (Saikal: 2004; 221) These hopes, although in many ways quashed, were in other ways fulfilled. Kandahar, the first major city to come under Taliban rule, was stabilized quickly. (Schofield: 2003; 335) The Taliban however went back on their promise of ending the opium trade and instead began to profit from it. (Maley: 1998; 9) In addition to this involvement with narcotics, they also began to impose laws that interpreted Islam in the most draconian ways. (Ewans: 2002; 186-187) Iranian religious leaders have criticized this form of Islam as 'fossilized'. (Ferguson: 2004)

The Taliban controlled most of Afghanistan, approximately 90\%, from 1996 until 2001. (Ferguson: 2004) Although they managed to stabilize a significant amount of the country, the hopes of a regime that would bring safety to Afghanistan was quickly dashed. The Taliban interpretation of sharia laws were strict. (Ferguson: 2004, Pazira: 2005) The Taliban ruled through terror. They held such strict control over the Afghan population through the use of harsh laws and harsher punishments. The human rights abuses, in specific the gender based apartheid that the Taliban instated in Afghanistan, 
are well documented. Some key factors in that gender based apartheid were the compulsory veiling, and seclusion and isolation of women. This practice went to the extent of prohibiting women's involvement in work or public education. Adding salt to the wound was the fact that there were between 30,000 to 50,000 widows in Afghanistan at the time; women who were no longer able to earn a living nor had husbands to support them. (Ferguson: 2004) Every day activities such as kite flying; the playing of music; women's wearing of white socks were all banned and labelled offences against God. (Schofield: $2003 ; 346$ ) The atrocities caused by the Taliban regime are numerous and horrific. Although there were international cries for help, the humanitarian cause was largely shrugged aside by the international community. (Ferguson: 2004) This destruction continued for close to seven years under the Taliban.

The events of September $11^{\text {th }}, 2001$ brought international focus back to Afghanistan. Osama bin Laden and his Al Qaida were stationed in Afghanistan. (Ferguson: 2004) It is this connection, and the failure of the Taliban to turn over bin Laden, that brought American fighter planes and the bombs they dropped over Afghanistan on October $7^{\text {th }}, 2001$. (Schofield: $2003 ; 348$ ) In the period leading up to the American military campaign Afghans became increasingly aware of the danger of war they once again faced. Many fled, again, to Pakistan where most were turned away at the now officially closed border. (Schofield: $2003 ; 348$ ) Kabul fell in mid-November to American led forces and once again the international community became involved in Afghan reconstruction. (Schofield: 2003; 348, BBC) 


\section{Afghanistan's Path to Democracy - Following the Reconstruction Process:}

In the few years since the American led invasion, the international community has begun to aid in the reconstruction of Afghanistan. Afghanistan, its population, government and the international actors working on its behalf continue to face immense hurdles. The expulsion of the Taliban from the seat of power was only one step on the road to creating stability and a democracy. The purpose of this portion of the chapter is to identify the main actors, both international and national, who are involved in the reconstruction and highlight potential pitfalls on the path to democratic reconstruction. Some of these challenges are shared by all other post-conflict societies attempting to attain democratic status, such as East Timor and Kosovo. Other challenges are more specific to the Afghan situation in particular and are an extension of the historical situation already described.

The international community is and has been heavily involved in the reconstruction of Afghanistan. It has been said that the goal of developing democracy in Afghanistan was a knee jerk reaction to the American led military invasion. (Thrupkaew: 2003) The argument is that the conquering force felt the need to legitimate its overwhelming presence in Afghanistan by installing a democracy in its wake. Whether this was the true motivation on the part of the United States and other international actors in whole or in part is up for debate. However, the perceived need of the international actors who brought more war and destruction into Afghanistan to legitimate their presence in that country is very present and pressing. The establishment of a functioning democracy would to some degree legitimate the military invasion because of the high legitimacy ascribed to democracy in and of itself. This is particularly important as for 
many (in particular the American public) the invasion was seen as an exacting of revenge by the American forces for the September $11^{\text {th }}$ attacks. (Wings Over Afghanistan: 2002)

Legitimacy is an ever present theme in the discussion of democratic development in Afghanistan. The lynch pin holding the collected efforts of together is this notion of legitimacy. Without democratic legitimacy Afghanistan is simply entering another phase of rule by force and/or local patronage. Democracy, therefore, is the legitimizing goal of the international actors who have become involved there. It is also arguably a goal of Afghanis themselves. The purpose here is to examine the process through which that legitimacy is achieved: the manner in which democracy is evolving in Afghanistan.

The cost in Afghan lives, in the 2001 military invasion, was large. The tally ranges from 3000 to 3,767 civilian casualties by mid December 2001. (Hyland: 2001) This statistic, taken together with the aftermath of the Taliban government meant that there was no basis or structure for the Afghan state. The challenges for Afghanistan's development and democratization are enormous. In this section of the thesis I will delve into the complexities of internationally led reconstruction of the Afghan state paying particular attention to the democratic aspects of the reconstruction.

This section provides a focused look at the roles of the Afghan leadership as it evolved from the Afghan Interim Authority to the Transitional Authority and now makes up the Government of the Islamic Republic of Afghanistan, as well as United States of America, the United Nations and NATO, and other international players involved in the reconstruction process. In particular I will attempt to isolate the goals that these international actors have identified for the development of Afghanistan. I will examine the realities of their work with specific attention paid to the process of democratizing the 
country. Democracy is a key goal for Afghan reconstruction, however, it has been largely shaped by those outside Afghanistan. Democracy in Afghanistan is fragile at best. The key to its success lies not in the actions of others but the ownership of the process by Afghans themselves and the establishment of a safe and secure state within which this process can flourish. Although Afghan ownership is necessary it is not the only necessity. To argue the necessity of Afghan ownership must not be motivated by a desire to disengage on the part of the international community.

The first efforts of internationally led reconstruction began in November 2001. The Bonn conference was carried out over nine days of meetings that brought together different groups from within Afghanistan as well as international leaders. (Schofield: 2003 ; 348) This Accord was hastily developed and signed. Within these short nine days, a group of notable Afghans as well as interested international leaders drafted what became the basis for the Afghan Interim Administration and the Afghan Transitional Authority. In addition to dictating the road to the development of democratic governance, the Bonn Agreement mapped the development of the constitution that quickly followed. (Schofield: $2003 ; 348$ ) More simply it is "only a preliminary step towards a postwar order." (Suhrke et al: 2002; 876) The Bonn Agreement is not a peace agreement but merely a "statement of general goals and intended power sharing". (Suhrke et al: 2002; 877) The Bonn Agreement lays claim to a number of broad and lofty goals for the reconstruction process. For example it acknowledges "the right of the people of Afghanistan to freely determine their own political future in accordance with the principles of Islam, democracy, pluralism and social justice...". (Agreement on Provisional Arrangements in Afghanistan Pending the Re-Establishment of Permanent 
Government Institutions: 2001) It also sets forth the plan for the development of a full democracy within Afghanistan. (World Press Review: 2002)

The Accord has been criticized as at best providing the "rudiments of a system that will help in setting up the infrastructure of state". (Rasanayagam: 2003; 256) However development beyond the provision of a rudimentarily guidance system seems impossible in a country "where there is no administration and guns remain the reality." (World Press Review: 2002) The other major criticism facing the Bonn Agreement is the fact that due to the hasty nature in which it was written, it lacks specificity on how reconstruction will unfold. (World Press Review: 2002) Despite these critiques, the Bonn Agreement has provided the reconstruction process with a structure with which to move forward.

The international community continued to keep Afghanistan's reconstruction on the table. In January 2002, the Tokyo reconstruction plan was drafted in which various United Nations members promised 4.5 billion US dollars in Aid to be delivered over the next four years. (Schofield: 2003; 349, UNAMA) The monetary aid so desperately needed in Afghanistan was recognized by all. Colin Powell warned that the reconstruction was likely to fail without continued assistance. (Schofield: 2003; 350) Financial aid was added to with peacekeeping aid at this time. International Security Assistance Force (ISAF) troops arrived that same month. (BBC) The ISAF was created in accordance with the Bonn conference and is governed by a series of UN Security Council resolutions (UNSC resolutions 1386, 1413, 1444, 1510). (NATO, UNAMA) The original arrangement for ISAF leadership was to be a six month rotating position, requiring a new lead country twice a year. This plan proved to be too challenging. The realities of 
having a new leadership every six months that had to start fresh in the situation combined with the need for suitable lead countries to volunteer for the position placed undue pressure on the ISAF force. (NATO) For these reasons the ISAF has been NATO-led since August 2003 and financed by troop contributing countries. (NATO) As of November 2004 ISAF has 8000 soldiers from 47 countries, both NATO members and non-NATO members. (NATO, Jawad: 2004)

The role of ISAF is to assist the Government of Afghanistan and the international community in maintaining security. (NATO) ISAF supports the government of Afghanistan "expanding its authority and providing a secure and safe environment, free and fair elections and spread the rule of law and the reconstruction of the country." (NATO) ISAF was originally mandated to safeguard Kabul and the surrounding area as the American led coalition was still active in the rest of Afghanistan. Although Operation Enduring Freedom continues to be underway as of October 2005, ISAF have been able to expand its mission to include the safeguarding of nine northern provinces. There are, in addition, plans to move, for the first time, into western provinces later this year (2005) with an additional 900 troops on the way. (Norton-Taylor: 2005) In the areas outside of Kabul, ISAF is involved in a variety of reconstruction projects including providing security for aid workers, training police, rehabilitating schools and medical facilities as well as having provided security during the 2004 election. (NATO) The Provincial Reconstruction Teams (PRTs that make up ISAF outside Kabul) are almost exclusively under the command of the US led Operation Enduring Freedom (all except the one in Kunduz as of April 2005). This American led operation continues military action in Afghanistan aimed at terrorist targets. (NATO) Although the ISAF claims to be 
a part of a three way partnership, with the United Nations Assistance Mission to Afghanistan (UNAMA) and the government of Afghanistan, it is clear that due at least in part to the continued American command of the PRT's and areas outside Kabul, the ISAF is much less a partner to UNAMA and the government than it is a subject of the American operation. (Lieven: 2005)

Although they have been hugely invested in the post 2001 era in Afghanistan, the United States has been involved in Afghanistan since long before the 2001 invasion. Originally supporters of the Taliban, American policies shifted when it became apparent that, among other things, the Taliban had become involved in the opium trade instead of becoming a partner in the war on drugs. (Ewans: 2002; 163) The United States identified the goal of the military conduct in Afghanistan as the defeat of terrorism and "specifically to deny terrorists any safe haven in Afghanistan." (US House of Representatives: 2004) The resolution to make Afghanistan a country that is no longer a safe haven for terrorists and the establishment of a democracy in the country are the motivations clearly expressed by both President Bush and the United States House of Representatives. (US House of Representatives: 2004, Jawad: 2004)

It is important to note that although the American forces are focused on the elimination of any and all terrorist threats in Afghanistan, the United States have in some way been a driving force behind every stage of Afghan reconstruction. The United States has been the largest single state donor to the reconstruction process in particularly aiding in the October 2004 presidential election. (US House of Representatives: 2004) William H. Taft, the Legal Advisor to the Department of State, reaffirmed on the behalf of President Bush that "the United States will continue to be a full partner in Afghanistan's 
reconstruction". (2003) He also stated that the United States would support President Karzai's goal of reconstruction and therefore the "United States will focus its efforts on particular projects in the areas of transportation, agriculture, education and health." (2003) The goals of the United States authorities are that Afghanistan become a stable country through the establishment of a democracy. (Armitage: 2004)

The United Nations is another key actor in the reconstruction of Afghanistan. The UN orchestrated both the Bonn (held December 2001) and the subsequent Tokyo Conferences (held in January 2002). These conferences have established a plan for reconstruction, at least of the political arena, and provided some funding toward that reconstruction. In addition to these, there is also the ISAF that was established through a UN Security Council resolution. The UN mandated and thus authorized NATO troops through the ISAF. Finally there is also an active UN mission in Afghanistan. The United Nations Assistance Mission in Afghanistan (UNAMA) is active in integrating all UN activities in Afghanistan, promoting national reconstruction and fulfilling the roles allocated to the UN in the Bonn Conference. (UNAMA) These roles include assisting with the establishment of an "independent human rights commission, investigating human rights violations, recommending corrective action and implementing a program of human rights education". (UNAMA) Despite its varied roles, the UNAMA has adopted the 'light footprint approach' meaning it is relying on as few international staff as possible in an attempt to 'work themselves out of a job' and build the capacity of the Afghan government. (Chesterman: 2002; 3)

Simon Chesterman is a noted scholar and the director of the International Peace Academy's program on Transitional Administration which focuses on the role of the 
United Nations in state building activities. He points out that on paper the "UNAMA resembles earlier assistance missions that provide governance and development support to post conflict societies." (2002: 3) By earlier missions he is referring to similar state building initiatives the UN has undertaken in cases like Kosovo and East Timor. In reality, however, Chesterman argues, the fact that the mission is intimately involved with the Afghan government represents a shift in UN state building policy. The close ties between UNAMA and the Afghan Government create a "disjunction between formal authority and practical influence". (Chesterman: 2002; 4) The continuing relationship between the UNAMA and the Afghan government translates into an influential role of the UN in the reconstruction of Afghanistan without the appearance of such a role. The close ties between the UNAMA and Afghan government are not necessarily detrimental but the appearance of Afghan authority is undermined by the reality of heavy external influence. The greatest challenges will continue to be increased Afghan ownership of the UN/Bonn conference mandated process and the increasingly hands off approach needed by the UN.

Perhaps the most important partner in this reconstruction process is the Afghan government itself. The Bonn Agreement laid the framework for the establishment of a 'soon-to-be' democracy within Afghanistan. (Rasanayagam: 2003; 257) An emergency Loya Jirga, a council of approximately 1500 powerful members of the various ethnic and tribal groups in Afghanistan was held immediately following the Bonn Conference (this term, Loya Jirga, traditionally refers to a council of elders). It was the role of this Loya Jirga to select the leader of the Afghan Transitional Authority. (UNAMA) The emergency Loya Jirga has been widely criticized for its inclusion of warlords and war 
criminals, human right abusers and militia leaders. (Kohi: 2004) As Chesterman points out;

Few people delude themselves into thinking that the Loya Jirga was a meaningful popular consultation - the aim was to encourage those who wield power in Afghanistan to exercise it through politics rather than through the barrel of a gun. $(2002 ; 6)$

The Loya Jirga carried out the task of selecting the President, Hamid Karzai, of the Afghan Transitional Authority (ATA) in June of 2002. (BBC) Attempts to intimidate members of the Loya Jirga and influence their vote were made by various warlords or local commanders during the selection process of Karzai and at other crucial decision making instances. (UNAMA) By attempting to induce local militia leaders into adhering to the democratic process, the process has in fact been weakened. While the exclusion of these leaders would have prevented the fast paced reconstruction currently underway in Afghanistan, by formalizing their role within the democratic process their status as warlords, human rights abusers and militia leaders has been legitimated.

The emergency Loya Jirga members in turn became internally elected members of the Grand Council that adopted the constitution in January 2004. (The Constitution of The Islamic Republic of Afghanistan: 2004) The constitution lays the groundwork for a government that is respectful of international law, human rights and "based on the people's will and democracy". (Constitution of the Islamic Republic of Afghanistan: 2004; Preamble) According to the constitution, the Afghan government "consists of a powerful and popularly elected President, two Vice Presidents, and a National Assembly consisting of two Houses: the House of People (Wolesi Jirga), and the House of Elders (Meshrano Jirga)." (Tarzai: 2005) 
In 2004, the country took another step towards democratic reconstruction with the presidential election. This election was heralded as "a heroic milestone" and an "unprecedented success". (USAID: 2004) Eight million Afghans turned out to vote, an estimated 70 per cent of registered voters. (USAID: 2004) Out of the 41 percent of registered women voters, 40 percent made it to the polls. (USAID: 2004, UNAMA) Karzai was declared the President with 55 per cent of the votes. (UNAMA)

Criticism of the electoral process was audible before the event as well as in its wake. The Revolutionary Association of the Women of Afghanistan (RAWA) argued that there was no possible way that the presidential elections would be a free forum for the peoples of Afghanistan to express their will. "Guns, money and intimidation rule over and influence the law." (RAWA: 2004) agents...

"The "Election Commission" is occupied by the warlords and their

"Over 150 complaint letters have been submitted by the victims against the above criminals, but the Commission has rejected them all. The Election Commission breached election law and opened the door for these bloodthirsty warlords...

"The election result is already known; Karzai will win. This is not a prophetic prediction. People are left with no other option but to choose between Karzai and the criminals." (RAWA: 2004)

Despite all the controversy surrounding the election President Hamid Karzai currently rules Afghanistan with the legitimacy that the title "democracy" affords him. $\mathrm{He}$ is quoted as saying that "After decades as a silenced nation" his country was "beginning to have a voice of its own". (Hagen: 2002) According to Karzai "This success, the participation of the Afghan nation in elections proved that the Afghan nation knows its interests and that is wants a bright, prosperous and peaceful future, in which 
there will be rule of law." (Karzai: 2004) The heavy amount of focus on the elections provides an example of LID and will be discussed in more depth in Chapter 3.

The parliamentary election, much like the presidential election before it, was postponed multiple times. (Cheragh: 2005) The most recent postponement happened in March of 2005; the election finally took place on September $18^{\text {th }}, 2005$. (Katzman: 2005; 5) The results, like the election itself, were also delayed multiple times, largely due to allegations of fraud in the Kandahar province. (Synovitz: 2005, b) Fraud allegations also led to the release of fifty Afghan election staff and the removal of three percent of ballot boxes from the count that had clear signs of tampering. (Synovitz: 2005, b) Despite these hurdles the official election results were released on November 12, 2005. (JEMB: 2005)

The elected members now face a challenge more difficult than running. The People's Council (Wolesi Jirga) and provincial councils are made up of hundreds of people, 249 Wolesi Jirga members and 420 Provincial Council members to be exact. (JEMB: 2005) The vast majority of these ran as independents during the election. (Tarzi: 2005) Although there are clear coalitions forming, the future of these Councils is impossible to know. There are four major (although overlapping) groupings currently identified in the Wolesi Jirga: former mujahedin, independents (technocrats and tribal leaders that are not associated with any party, former communists and finally former Taliban. (Tarzi: 2005) The expectations now riding on this highly polarized and fractious government are very high. It is entirely possible that the government will be unable to function due to its fractious nature.

Afghanistan faces countless challenges in the reconstruction process. It may be true that "the Afghan people now have high expectations for the new Government to 
deliver on security and reconstruction, and to do it on the basis of the rule of law and a commitment to transparency and accountability." (National Human Development Report (NHDR), Foreword by Karzai: 2004) However the continuing situation leaves little hope that this new Government has the ability to fulfil any of these goals. Insecurity in Afghanistan is not only a problem of physical safety, but also of deprivation and restricted access to health and education facilities, legal and political rights and social opportunities. (NHDR: 2004; 1) The worsening security environment in the post intervention era has, according to Jennings, left many nostalgic for the predictability of the Taliban regime. (Jennings: 2003; 22) This depressing reality is compounded by the horrific standards of living in the country. A recent National Human Development Report "has painted a gloomy picture of the status of human development in the country after two decades of war and destruction. The Human Development Index (HDI) value calculated nationally puts Afghanistan at the dismal ranking of 173 out of 178 countries worldwide." (NHDR, Foreword by Karzai: 2004) The extreme poverty is crippling and compounding the problem further are issues with financial aid. There are continuing problems with coordination of funding, and lack of funding (Ferguson: 2004, Jennings: $2003 ; 21)$ Afghanistan has received perhaps half of the US\$ 4.5 billion pledged and that is under a quarter of the 20 billion US dollars that is reportedly needed to rebuild the country. (Thrupkaew: 2003) This delay in aid, and resulting poverty, has left many Afghans dependant on old 'clan' networks, thereby entrenching local feudal identification and weakening national identity. (Ferguson: 2004) 


\section{Conclusion:}

The reconstruction of Afghan civil society and the construction of a democracy there are costly and long term endeavours. Ignoring the history of the country and the realities that that history has on present day Afghanistan can only work to increase the capital and time needed to accomplish this goal of reconstruction. It is, of course, probable that the international actors involved intimately knew the history of Afghanistan. It is not evident that they paid this history much attention. The people of Afghanistan have a history of fierce resistance to perceived external influence. Given the 'ebb and flow' of conquest and international intervention that has occurred throughout Afghan history it is not hard to understand the root of this resistance. This resistance comes to the forefront as international actors play a crucial support and aid role in the reconstruction of the country.

The resistance is compounded with internal fractionalization. The efforts being made to unify the country under one central government headed by President Karzai are not currently sufficient to create the national identity needed to bond the country and strengthen the emerging democratic government. Afghanistan continues to face many challenges on the road to reconstruction. The formation of an active and engaged civil society that contributes to the political process is dependant on how fully the fractional elements in Afghanistan can connect under a common goal and on how much they have to say in the new 'democracy'.

History leaves its legacy or burden on today and tomorrow. If history is understood than the current situation can be better understood within its context. The history of international, and often forced, involvement of all kinds in Afghanistan and the 
resulting fierce resistance to that interference needs to be in the minds of both the members of the international community and the Afghan leaders working toward the establishment of a democracy in Afghanistan. 


\section{Chapter 3:}

\section{How Democracy is being Developed or Underdeveloped in}

\section{Afghanistan}

\section{Introduction:}

There are two essential questions at the heart of this thesis; the 'how' of democracy and 'why' of democracy. The 'how' question refers specifically to how democracy is implemented in the Afghan case. How exactly is the Afghan democracy developing? What is the process, landmarks and setbacks? What are the challenges? Although there are many instances of international intervention, aid and or involvement in the process of establishing democracy in a state, Afghanistan presents itself as a currently unfolding, complex case. 'Why democracy', in turn, examines the reasoning behind the international promotion of democracy in Afghanistan as only the latest example of an international trend. Democracy is promoted internationally as the best political system for all states, regardless of culture, faith, or tradition. Are there any contexts in which democracy is not appropriate, or not the most appropriate solution? And why is democracy promoted so pervasively when the actual democracy that is born so often falls short of democratic ideals, such as those outlined in chapter one? The study of the case of Afghanistan gives a window through which to view and further explore these questions. This chapter focuses on the question of 'how democracy'. It will show that although the structure for democracy is to some extent being built in Afghanistan, the structure alone, especially in such a hollow form, is not enough to sustain or promote democracy. 
I argue that the type of democracy that the Afghan government and the international community professes to be developing in Afghanistan is a liberal representative democracy as described in chapter one. Whether the intention is truly the establishment of this form of democracy or some other government there is a clear formal identification of a liberal representative government as the preferred model for governance. This identification is made through the examination of the formal developmental steps Afghanistan has made towards democratic governance. It is true however that there is no statement, manifest or outline available that proclaims Afghanistan to be a liberal representative democracy in development. The indications that identify Afghanistan as a potential liberal representative democracy can be found in the Bonn Agreement, the Constitution of the Islamic Republic of Afghanistan as well as the elections all previously described in chapter two. The purpose of this chapter is to look in more detail at these procedural steps towards the development of democracy in Afghanistan. These procedural steps made in Afghanistan all point to the adoption of a liberal representative democracy. However, when examined in detail or in practice each stage of the development of democracy is marred by extremely undemocratic events.

\section{Liberal Representative Democracy:}

Democracy is a term that embodies many different ideas and can be used to mean any of them. In chapter one, I outlined my working minimum standard of democracy. Combining David Held's discussion of liberal representative democracy with Hutchinson and Monahan's conception of a thin version of the rule of law, I identified the minimum characteristics of democracy as: a system of governance in which the government is 
popularly elected through free and fair elections. (Held: 1995; 12) Each citizen will have a vote with equal weight regardless of sex, class, religion. (Held: 1995; 12) It will include freedoms of consciousness, association and the right of all citizens to oppose their government and for adults to run for office. (Held: 1995; 12) As well the rule of law, that states all citizens are equally accountable under the law, is included. (Hutchinson \& Monahan: 1999; 125)

In contrast to this working standard of democracy, I also outlined in chapter one, Susan Marks' caution regarding a trend she labels 'low intensity democracy' (LID). According to Marks the indicator of LID is: "where democracy differs little from authoritarian rule but enjoys significantly greater legitimacy". $(2000 ; 61)$ This is achieved through an electoral fixation that obscures the absence of other democratic developments. (Marks; 2000; 61) With these working standards in mind I will now examine the emerging democracy within Afghanistan.

One weakness in the model of liberal representative democracy discussed in Chapter 1 is that it is focused primarily on institutions active within democracies. Institutions are far easier to measure and examine than the more substantial aspects of democracy such as political participation by, and commitments of, the citizenry. Because institutions, laws and international agreements are the 'back bone' of democratic development in Afghanistan their examination here is necessary as well. As an outsider who has never had the opportunity to visit Afghanistan, I am dependant on official reports and documents for information. This, unfortunately limits my sphere of information such that while I can fully examine institutional developments that have been well documented and reported, I am not in a good position to touch on the less obvious 
aspects of Afghan democracy, including aspects of political participation that exist beyond the voting process: free association of individuals, the freedom of discussion and exchange of ideas. Therefore, I am open to the critique of being overly focused on institutions. I do, however, recognize this weakness and will attempt to address it below in a discussion of Marks' theory of 'low intensity democracy' as applied to post 2001 invasion Afghanistan.

The political institutions in Afghanistan that act to support the emerging democracy all appear at first glance to be liberal democratic institutions. I will examine these institutions; the Bonn Agreement, the constitution, the electoral law and both sets of elections (presidential and parliamentary) and draw out their structural elements that support a liberal representative democracy in Afghanistan. The second step in my analysis will be a closer examination of the institutions of governance at work in Afghanistan. It will show that the democracy there is far from developed and that in fact it is in danger of becoming an example of Susan Marks' low intensity democracy.

\section{The Bonn Agreement:}

What was the nature of the international Bonn Agreement that provided the basis for the development of Afghan democracy? The formula for development laid out in the Bonn Agreement point to the development of a liberal representative democracy. The agreement itself states that the interim arrangements it contains "are intended as a first step toward the establishment of a broad-based, gender-sensitive, multi-ethnic and fully representative government." (2001) This string of qualifications stress the importance of inclusiveness in the government. The liberal representative democracy as outlined in 
Chapter 1 also stresses inclusiveness in the qualification of universal suffrage. The criterion of universal suffrage should be able to translate into a government that is representative through the institutions of elections. The Bonn Agreement goes beyond stressing the importance of the establishment of a representative government to support elections. Section 1 (4) of the Agreement makes clear the link between the representative nature of the government and elections stating that the Transitional Authority as decided upon by the Emergency Loya Jirga shall "lead Afghanistan until such time as a fully representative government can be elected through free and fair elections..."

Elections are not the only criteria used to define liberal representative democracy. The ideal that citizens in a liberal representative democracy also enjoy the freedom of consciousness and the right to oppose government and to form independent associations is supported within the text of the Bonn Agreement. Section 5 (2) states that: "The Interim Authority and the Emergency Loya Jirga shall act in accordance with basic principles and provisions contained in international instruments on human rights and international humanitarian law to which Afghanistan is a party." Afghanistan was one of the original members of the United Nations to adopt the Universal Declaration of Human Rights (UDHR) in 1948 and has, after the 2001 intervention, reaffirmed this commitment. The UDHR is so significant, at least to the drafters of the constitution, that it is recognized in s. 5 of the preamble of the 2004 Afghan constitution. Articles 19 and 20 of the UDHR support the importance of political freedoms. Article 19 states: "Everyone has the right to freedom of opinion and expression; this right includes freedom to hold opinions without interference and to seek, receive and impart information and ideas through any media and regardless of frontiers." This article of the UDHR to which 
Afghanistan is a party speaks directly to the freedom of consciousness which liberal representative democracy ensures. Article 20, s. 1 of the UDHR states that: "Everyone has the right to freedom of peaceful assembly and association."

The Bonn Agreement provides insight on the starting point of the development of a democracy in post 2001 invasion Afghanistan. Following in the footsteps of the Bonn Agreement is the drafting and adoption of the Constitution of the Islamic Republic of Afghanistan. The constitution, like the Bonn Agreement before it, promotes, at least at its surface, the development of a liberal representative democracy.

The Constitution of the Islamic Republic of Afghanistan:

The Afghan constitution was adopted on January $4^{\text {th }}, 2004$ and was met with resounding international praise. The emergency Loya Jirga elected from among themselves members to the Grand Council that adopted the constitution. (The Constitution of the Islamic Republic of Afghanistan: 2004) Of course this constitution is multifaceted, encompassing sections relating to various areas of governance, including religion, natural resources, national assembly and so on. For the purposes of this work, the focus will be directed towards those parts of the constitution that work to establish the type of governmental structure the constitution prescribes. S. 7 of the preamble of the constitution specifically notes that the people of Afghanistan are "For establishing a government based on people's will and democracy." (The Constitution of the Islamic Republic of Afghanistan: 2004) The preamble goes on to state that the people of Afghanistan are "For the creation of a civil society free of oppression, atrocity, discrimination, and violence and based on the rule of law, social justice, protection of 
human rights, and dignity, and ensuring the fundamental rights and freedoms of the people" (Preamble, s. 8).

These two brief statements made at the outset of the constitution point directly towards supporting the argument that the type of government being developed in Afghanistan is a liberal representative democracy and it is augmented through the use of the rule of law. The constitution does in fact delve into more detail regarding the necessary aspects of liberal representative democracy. For example the second chapter of the constitution entitled "Fundamental Rights and Duties of Citizens" deals specifically with the rights of citizens in terms of equality before the law (Article 22), electoral rights (Article 33), freedoms of expression and organization (Articles 34 and 35). These are all rights that are integral parts of the liberal representative democracy as described by Held. Other articles in the constitution point to the importance of the rule of law.

The thin version of the rule of law, that is rule by law itself, can be seen in Chapter II, Article 56. S. 1 of this article states "Observing the provisions of the Constitution, obeying the laws, adhering to public law and order are the duties of all people of Afghanistan." The constitution goes on to focus on procedural matters regarding elections, powers and duties of the president and similarly focus on the government and role of ministers. This process of outlining both the responsibilities and the constraints of power of not only the president, Articles 60 through 70, but also the ministers that will work under the president, Articles 71 through 80 clearly employ the rule of law. These are the rules that are being set up to rule the country. They apply to those at the highest positions of power and focus not only on the manner in which their authority is used but also work to impose limitations on it. Liberal representative 
democracy, as well as a thin version of the rule of law are both foundational pieces to the Constitution of the Islamic Republic of Afghanistan.

\section{The Electoral Law:}

In May 2004, prior to presidential public elections, the Electoral Law was passed and came into force through presidential decree. Chapter 1 of the Electoral Law outlines general provisions of elections states "Elections shall be conducted on the basis of free, secret, universal and direct ballots." (The Electoral Law: Chapter 1, Article 2) Chapter one goes on to stress that all voters have an equal right to participation and that each voter can only vote on their own behalf. (Articles 3 and 4) The law sets up the role of the Independent Electoral Commission in an attempt to secure a free and fair election. It makes clear that there are attempts to regulate the manipulative use of power by prohibiting those in positions of military and administrative power from running for office. This prohibition includes everyone from officials in the armed forces to civil servants.

The 'representative' nature of liberal representative democracy is made especially clear in article 19 on the allocation of provincial seats for the Wolesi Jirga (the National Assembly's lower chamber, known as the People's Council or House of Representatives). (Synovitz: 2005, b) This article affirms that the proportion of seats allocated to each province is based on their population. The Electoral Law presents a regulatory system in which elections can take place. It attempts to secure free and fair elections through restrictions on the amount of time allowed for campaigning, the procedure through which complaints will be assessed and establishing electoral offences. The Electoral Law 
entrenches the role of the Independent Electoral Commission as a regulator and watchdog for all future elections in Afghanistan. This law embraces the role of elections in a liberal representative context. Free and fair elections are at the forefront of its focus and these will all take place through the implementation of rule by law in this case the Electoral Law.

\section{Presidential Elections:}

The historic first presidential election for Afghanistan took place in October 2004, just nine months after the new constitution came into force. Hamid Karzai, who led both the Afghan Interim Authority and the Transitional Authority, was formally elected president of Afghanistan. This was yet another step toward the establishment of a liberal representative democracy. Prior to the election measures were taken to encourage as many citizens as possible to take part in the election. A joint UN-Afghan committee was set up in order to register voters and organize the upcoming elections. (Katzman; 2005) This group, the Joint Electoral Management Body (JEMB), worked amid insecurity and violence in which its workers were able to register approximately 10.5 million voters (42\% of which were women) (Katzman; 2005).

In a 'post conflict' country such as Afghanistan, the extent of free and fair elections is severely limited regardless of the rules established in the constitution. This is due to high levels of violence, and local warlord or militia intimidation not to mention limitations such as illiteracy, extreme poverty and a populace that has not had the opportunity to elect a leader in over 25 years, let alone engage in democratic decision making. However through the establishment of the JEMB and the reinforcement of the 
ISAF for the election period, and other heightened security measures, those in power have attempted to secure as free and fair an outcome as possible.

\section{The Parliamentary and Provincial Elections:}

The parliamentary and provincial elections held September $18^{\text {th }} 2004$ went even further in attempts to ensure free and fair voting. A massive education campaign was undertaken to aid the people in the voting procedure. In addition to the education campaign, the JEMB through its sub committee the Electoral Complaints Committee (ECC) removed approximately 45 candidates from running on the basis that they were inappropriate candidates. Article 85 of the Constitution states that in order to serve as a member of parliament the candidate must be a citizen of Afghanistan (for at least the past ten years), not convicted of any crimes against humanity and must be at least 25 years of age to serve on the House of Representatives (Wolesi Jirga) and 35 years of age for the Senate (Meshrano Jirga). The results of these latest elections were not released until November $12^{\text {th }}, 2005$. (JEMB) Despite the delay in results this election has been widely praised in the international arena as the 'final step' towards the establishment of a democratic Afghanistan. (Entekhabi-Fard \& Franco: 2005)

\section{The Danger of Low Intensity Democracy:}

At all these various stages in the formal development of a new system of governance in Afghanistan, moves have been made in order to put a liberal representative democratic government with the rule of law in place. These moves have been public and 
formal, they have occured through the development of a formal system of governance, through the constitution and the electoral law, the establishment and monitoring of two separate elections. There is a danger in all of this that these attempts to establish a liberal representative democracy are not successful in the desired manner. Presidents Karzai and Bush along with the Secretary General of the United Nations and his Special Representative to Afghanistan have all been quoted advocating the nature of the government being established and praising the quick progress made in its actualization. This praise may serve to obscure the lack of democratic developments.

Despite the developments made and the high praise received there is a very real danger that this government is not developing in the way it is presented in the media by Afghan and international leaders in the reconstruction process. The issue of Low Intensity Democracy (LID) discussed in chapter one lends a tool for further analysis of the democratic development in the case of Afghanistan. If we look back to Marks' work we remember that LID can be identified through the focus on formality such as elections and the rule of law. (Marks: 2000; 52-53) These elections are the legitimating tools of LID. (Marks: 2000; 60-61) Marks could in many ways be describing the situation on the ground in Afghanistan. The formal equality and representative democracy established in the years since the 2001 American led invasion are potential smokescreens hiding what is in actuality a newly internationally legitimated authoritarian rule. I will now employ Marks' LID to further analyze the democratic institutions established in Afghanistan since 2001.

The Bonn Agreement, Constitution and Presidential and Parliamentary / Provincial elections have all been shown above to support the liberal representative 
model of democracy as described by Held and augmented by the thin version of the rule of law as developed by Hutchison and Monahan. It is true that especially in a cursory overview these formal processes demonstrate the move towards democracy in Afghanistan. The fact is that at each step along that route there are many other factors that go against the very democracy these institutions appear to espouse. Democratic institutions are not sufficient in and of themselves. "Neither democratic politics nor democratic institutions can be replacements for each other." (Luckham et al: 2003; 20)

The Bonn Agreement laid the ground work for the Afghan government and its path towards the development of a democracy. The Agreement also it makes an overture towards the 'Afghan mujahidin' that although was arguably necessary at the time can be seen as extremely detrimental to the development of democracy. It declares the 'Afghan mujahidin' "heroes of jihad and champions of peace". (Introduction) It is important to recognize that there is no definition given anywhere in the Agreement itself or its many Annexes that states who exactly are considered mujahidin. For many Afghans, as was witnessed in the discussion of history in chapter two, the armed Afghan militias who fought to oust the Soviets from power in the late 1980s are considered mujahidin. These are the same armed groups that later ruled their own small areas of Afghanistan through the barrel of a gun or who joined the Taliban, a group that also formed under the Soviet occupation. (Ferguson: 2004)

There are those who argue that "the mujahidin forfeited their title of heroes and assumed the mantle of criminals when they took Kabul in 1992 and turned their guns on each other and surrounding citizens". (Gannon: 2004) Although this is historically accurate as many of those who claim the title mujahidin were involved in the chaos and 
atrocities that occurred 1992-1996, the mujahidin or warlords are also responsible for renewed criminal behaviour in the post 2001 intervention era. Beginning with the intervention itself and the American - 'Northern Alliance' relations in which the American forces enlisted the aid of private militias in their war against the Taliban in exchange for arms and financial support. (Peake: 2003; 182) These men of power whether named warlords, mujahidin, or Northern Alliance commanders are all scrambling to maintain their local power. For this reason they have formally joined the 'democratization' project.

The Afghan leaders who contributed to Bonn Agreement included many of the most powerful regional commanders; it further solidified their status by positioning many of them within the new government. (Peake: $2003 ; 186)$ It also acted to legitimate the continued existence of armed groups within Afghanistan in stating that:

"Upon the official transfer of power all mujahidin, Afghan armed forces and armed groups in the country shall come under the command and control of the interim Authority, and be recognized according to the requirements of the new Afghan security and armed forces." (2001: S.5, ss.1)

Although this move provided a way to attempt to bring all the various armed groups under one central authority, it was short-sighted. It legitimated those that had used force as a form of control and gave them an official role in the new 'democratic' Afghanistan in which they could continue to use force. The mujahidin discussed in the Bonn Agreement are the same warlords that threaten the development of an Afghan democracy. Many are as radical in their ideology as the Taliban. (Gannon: 2004) Although there are those who would argue that warlords are creating stability in an anarchic situation and that this is in and of itself a good thing (Jackson: 2003; 147) the warlords act counter to 
the development of democracy through the continued rule through force and intimidation, corruption and drug trafficking. (Gannon:2004)

The Bonn Agreement was not the only example in which the image of democracy, of a free and fair society, presented a false conception of reality. The constitution of Afghanistan is very specific in its ruling that "no law can be contrary to the beliefs and provisions of the sacred religion of Islam." (Article 3) This provision is not in and of itself undemocratic. However it creates room for undemocratic measures. According to Held's liberal representative democracy model individuals have the right to have a freedom of conscious and expression, even in instances where they disagree with the government. Since this constitution was adopted there have been multiple arrests of journalists who are accused of blasphemy. (Committee to Protect Journalists: 2005) Currently Ali Mohaqiq Nasab, editor of the monthly magazine, Haqooq-i-Zan (Women's Rights), is in jail facing such charges. The magazine is accused of containing articles that are against Islamic teachings. Such severe censorship speaks to a deficit in the freedoms of consciousness.

Niaz A. Shah also takes a close look at the constitution of Afghanistan in her article "The Constitution of Afghanistan and Women's Rights". (2005: 239-258) Shah argues that the constitution deals with women's rights in three ways. She terms these neutral, protective and discriminatory. Neutral means making no distinction between the sexes; protective clauses promote specific women's rights; and discriminatory implications of the constitution, may appear neutral but, when understood in the context of Afghanistan are in fact discriminatory. $(2005 ; 224)$ She stresses the point that although Afghanistan has ratified the Universal Declaration on Human Rights and Convention on 
the Elimination of Discrimination Against Women, all conventions are "subject to Supreme Court review for compliance with the Constitution and if they do not conflict with Islamic law then they are applicable..." $(2005 ; 250)$ Supreme Court has the final say on whether a law is Islamic or contrary to Islam. For this reason, as well as the clear cultural and historic oppression of Afghan women, Shah is sceptical about the effect of the constitution equality prognosis.

Samina Ahmed argues that American manipulation of governmental institutions in Afghanistan has weakened its legitimacy stating that "a manipulated constitutional loya jirga has undermined the constitution's legitimacy." $(2004$; 15) Kathy Gannon again points to the involvement of warlords in this process citing that Abdul Rasul Sayyaf, a prominent and powerful Afghan warlord (and member of the constitutional loya jirga) met with the American Ambassador to Afghanistan, Zalmay Khalilzad, in the lead up to the adoption of the new constitution. The details of their meeting were not released but there is strong conjecture that a deal was struck in order to secure Sayyaf's support for the constitution. (2004) The rumours surrounding the deals for the constitution may just be rumors, however, there is still one point that leaves the constitution up for critique.

The constitution was not adopted by popularly elected body. The constitutional loya jirga were internally elected from the emergency loya jirga or grand council. These are internationally selected leaders of the various ethnic, religious and cultural groups within Afghanistan. (Peake: 2003; 186) The fact that the constitution was adopted before elections were held raises questions as to its legitimacy. Assuming the Afghan peoples did then and continue to desire democracy, specifically in its liberal representative form, the constitution provides clear advances towards that goal as discussed earlier in this 
chapter. The development of that democracy has to evolve in some way. It is a chicken or egg scenario where the constitution established a basic rule of law and electoral process, but was adopted by a group of Afghans who were not themselves elected. This is the path that the Bonn Agreement set out for the development of this democracy. The constitution has been proclaimed 'enlightened' and 'progressive'. (Rubin, E.: 2005) This description is somewhat misleading as shown above as the constitution has the potential to limit some of the civil liberties fundamental to liberal democracies as easily as entrench them. Regardless of its potential the constitution falls vulnerable to the weakness that it was not adopted by an elected body.

The presidential election, like the constitution, was internationally heralded an "unprecedented success". (USAID: 2004) The United States considers carrying out the elections to be a victory in the war on terror. (Kohi: 2004) Others claim that the election was compromised by irregularities. This is seen through a series of 'letters to the editor' in various newspapers, such as the Afghan Daily, Kabul Press and the Dawn, at the time. There were allegations of fraud and ballot stuffing. (Rahman: 2004) One of the most damaging aspects of the election's credibility was the 'indelible ink', the safeguard against multiple voting easily rubbed off the fingers of voters thus allowing them multiple turns at the polls. (Rahman: 2004) There are also those that claim that the voting was influenced through intimidation and limiting access for women and the poor. (Jennings: 24, Jalali: 2003; 177) In addition to these concerns the fact that Karzai had access to financial and logistical resources, not to mention a private security force, that other candidates did not, suggests unfair advantage at the outset. (Pazira: 2005) In response to these criticisms an internal investigation team was formed through the Joint 
Electoral Monitoring Body and although they did find "voting irregularities" they did not find them sufficient to have had an effect on the outcome. (Rahman: 2004) Karzai was declared the President with 55 per cent of the votes. (UNAMA)

Many feel President Karzai is an idealistic nationalist. (Gannon: 2004) Despite his own beliefs "Karzai has failed to foster the spirit of nation building". (Rashid: 2005) Building a national identity within Afghanistan is an important unifying tool, useful in reconstruction. As it stands the Afghan government is headed by an elected leader. The remainder of the government are members that have been either appointed by President Karzai or appointed as representatives of their various ethnic or religious groups. (AI: 2004) Karzai has stated that "There will not be any private militia forces in Afghanistan. That is the first demand of the Afghan people." (Karzai: 2004) This goal is both important for the establishment of a democracy and stability in general. Despite this claim by Karzai, "One of Afghanistan's most notorious warlords is to serve as chief of staff to President Hamid Karzai with responsibility for the country's armed forces" (the warlord is General Dostum, he has been accused of war crimes). (Guardian UK: 2005) Ahmed Rashid adds that "He has appointed known drug dealers and abusers of human rights as governors and many of his ministers have gained reputations for rampant corruption". (2005) This move suggests that even though Karzai would like to do away with private militias he still needs their support in the day to day management of the country. Once again the inclination to include these individuals does a disservice to the rule of law.

President Karzai's authority is limited by both the international community that control the majority of funding for the Afghan government and the various local militia 
leaders. However, the postponement of the parliamentary and provincial elections provided President Karzai with almost an entire year as a lone elected official. As one editorial article, in the Afghan Daily newspaper, astutely pointed out "Without parliament, the government, in the guise of a presidency, is an authoritative kingdom that imposes the dictatorship of the minority on the people under the name of democracy." (Cheragh: 2005) The image described above mirrors exactly the low intensity democracy Marks describes: "where democracy differs little from authoritarian rule but enjoys significantly greater legitimacy" $(2000 ; 61)$

Despite fears that they might have been postponed to an even later date the parliamentary and provincial elections were finally held September $18^{\text {th }}, 2005$. The results of this very complicated electoral process were released November $12^{\text {th }}, 2005$. (JEMB: 2005) The councils that these elected members will make up have yet to meet (as of early December, 2005). (Tarzai: 2005) Many factors surrounding this round of elections however also point out indicators of a democratic deficit and the potential for a low intensity democracy. One of these factors is the lower than expected voter turnout. Although there was a massive education campaign to promote and ease the voting process the turn out estimate is at approximately $50 \%$ of the eligible population. (BBC) It may be important to note that many 'developed' democracies also suffer from a low voter turn out, however this $50 \%$ statistic was definitely lower than expected. Some explain this statistic with the Karzai administration's lack of effectiveness. One voter is quoted as saying that "President Karzai made big promises to us and nothing appeared." (Gall \& Sengupta: 2005) Others complained that the candidates all had blood on their hands. (Entkhabi-Fard \& Franco: 2005) Low turnout can also possibly be attributed to confusing 
electoral process. Each ballot was the size of a newspaper and in some areas had literally hundreds of candidates to choose from. (Entkhabi-Fard \& Franco: 2005) Voter apathy is not unique to Afghanistan. In the process of developing a new democracy it would be more reassuring to see the numbers of voters increase rather than decrease over time.

There were two major issues surrounding the candidates in these most recent elections. Already mentioned is the comment that the candidates had blood on their hands. By this the commentator likely meant that the candidates were warlords, militia leaders, mujahidin or individuals who are strongly backed by such forces. The ECC had set up a process under which complaints could be brought up against candidates could be heard. The only candidates that were disqualified, however, were those whose ties to currently armed militias could be proven. (Human Rights Watch: "Campaign Against Fear"; 2005) The Afghan Electoral law prohibits those that have been convicted of past crimes as already discussed in this chapter. Of course there has not been any court to prosecute the many that have been accused of crimes against humanity in the brief years since the 2001 invasion. (Human Rights Watch: "Campaign Against Fear"; 2005) Therefore, by Sept 16, 2005 the ECC had "disqualified only 45 low-profile candidates, while several of the most powerful strongmen remain on the ballot" (Smith: Sept 17, 2005) In addition to warlords as politicians the 'climate of impunity' also made room for intimidation campaigns against the female candidates in these elections.

The women who presented themselves as candidates in the Parliamentary and Provincial elections were brave indeed. Although there are a certain number of seats reserved for women in the Afghan government, the doors are not fully open for women in public office. Human Rights Watch cites a pervasive atmosphere of fear for women 
involved in politics. (HRW: Aug 17, 2005) This fear is rooted in the very real danger they face. In addition to general harassment many women faced death threats over the course of their campaign. (Massoud: 2005) "Election observers say tradition remains a formidable obstacle for women planning their campaigns, because it is almost impossible for them to travel unaccompanied by a male relative, especially in rural areas." (Massoud: 2005) There is also the reality that traditional Afghan culture ensures that very few men will consider voting for a female candidate, as one candidate's son pointed out "Mullahs came and said, "If you vote for a woman it is against Islamic law"". (Stockman: Sept. 19, 2005) Although incidents like this occurred across Afghanistan the election took place amid relative security and one apathetic voter ironically commented that if he were to vote he would vote for a woman because no woman would have blood on her hands. (Rubin, E.: 2005)

In addition to candidacy, issues the electoral law presents a threat to elected officials once the count has been completed. The new members of legislature are also subject to the potential for future violence as identified by Human Rights Watch. Losing candidates may take the seats of winners in the event of their resignation or death. (Assassination clause) The suggestion here is that second place candidates may have an incentive to assassinate the winner.

The debate that this analysis generates centers on: whether these democratic shortcomings will be areas for future development or point to a hollow process that merely gives the appearance of a democracy. Vikram Parekh, a senior analyst at the International Crisis Group, has described the American policy in Afghanistan as "a very improvised political strategy essentially designed to give an appearance of stability in 
Afghanistan." (as quoted in Gannon: 2004) He further argues that the US and the UN are following a 'checklist strategy' and doing very little to ensure stability. (as quoted in Gannon: 2004)

As Noam Chompsky points out in his work The Struggle for Democracy in the New World Order "we find that these guardians of world order have sought to establish democracy in one sense of the term while blocking it in a different sense." $(1993 ; 80)$ The establishment of institutions of democracy; constitutions, elections, rule of law in Afghanistan is potentially a facade, obscuring the realities of corruption, warlordism and instability.

\section{Conclusion:}

Given the short time in which democratic reconstruction has been underway in Afghanistan it is difficult to argue conclusively that the democracy there is, and will continue to be a low intensity one. However, at this early date the democracy being established appears to be surface level only. It does not have the fortitude nor the international support necessary to develop as a substantive democracy in which there is universal suffrage, freedoms of expression and association and an established rule of law.

Afghanistan's fledgling democracy is as precarious as a house of cards. The fragile structure of democracy built there is undermined by the parties involved, war lords as members of parliament and national military leaders. The outlines of the democratic institutions are in place, they are the rules and regulations that have been signed off on, but are still far from fully implemented. Asking the democracy that has thus far 
developed in Afghanistan to function, let alone function on its own, is a risky a proposition. 


\section{Chapter 4: Contradictions in Internationally Led Reconstruction;}

\section{The Necessary Weakness}

Introduction:

In the previous chapters I focused on the events in Afghanistan and its recent attempts to institute a liberal representative democracy. This chapter aims at examining the larger picture of internationally led reconstruction efforts, and addresses the question of why democracy is promoted as the ideal form of 'post conflict' government. Asking why democracy is promoted to the extent of imposition in reconstruction efforts is in many ways asking the unanswerable question. As discussed in chapter one, democracy has, in and of itself, a moral legitimacy and authority that makes it appealing. Because democracy is legitimated through the participation of the peoples it rules over, it gives the impression of fairness and justness.

Personal freedoms such as the freedom of expression, association and movement are integral elements of democracy, especially liberal representative democracies. Democracy is often used to imply these freedoms. Internationally led reconstruction efforts, with or without the cooperation of the local community, work to install democratic governance in 'post conflict' societies. This necessarily takes the form of some kind of imposition. Can democracy be imposed? If it is, what are the implications of 'imposed freedom'? How is this complicated by the need for more international involvement (and therefore more imposition)?

The tensions between the imposition and the freedom instituting system that it is imposed appear time and again in various forms within the literature having to do with 
reconstruction of a 'post-conflict' society. It is this uneasy point of paradox that require more focused attention. I argue in this chapter that this contradiction, a freedom that is imposed, is an essentially dangerous pitfall to the development of that democracy itself. Further, I argue that it is unavoidable in some form or another for actors engaged in international reconstruction of 'post-conflict' societies. The choice of the international community is simply the deciding the amount of involvement it will engage in at all levels of reconstruction.

The international involvement in reconstruction efforts is counter balanced by involvement of local leadership. Local ownership can be understood in different ways. According to the United Nations Development Programme "Local ownership is achieved when local actors initiate, plan and/or organize dialogue processes on their own, and are responsible for the results and completion of a project. Also, when the local public feels included and has a stake in the goals and results of a dialogue process." (UNDP) This can take the forms of policing, governance, aid work and rebuilding. The amount of local ownership in the reconstruction process in Afghanistan is largely dependant on the international community involved there. At least such was the situation at the outset of the reconstruction.

Local ownership is a valuable asset to any reconstruction effort, it carries the power to instil legitimacy and engage the local population. It can also be detrimental if its capabilities are overestimated and/or it is under-funded. Local ownership in 'post conflict' societies is desirable, but the local actors and the international community must both be realistic about the actual capacity of the emerging local governments before 
handing over the responsibility and consequently the burden of establishing a secure and just democracy.

Why is democracy the form of government chosen for 'post-conflict' societies?

The subject of international military intervention is a vast although closely related topic to the topic of internationally led reconstruction of 'post conflict' societies. The scholarship on international intervention is immense. It is an area too large and too important to be summarily dealt with in this work. Suffice to say that international intervention is a trend that in the recent past has increased in frequency and become more acceptable in the realm of international law. The Westphalian system, established through the 1648 Peace of Westphalia, has long established the rule of non intervention in sovereign territories. (Shaw: 2003; 1015) Of course this rule was, at the outset, only applied to a collection of European nations that served as the basis of the nation-state system, it is now applied around the world. (Shaw: 2003; 1162) The international community has found, increasingly in recent years, reasons to 'legitimately' intervene in various states, therefore circumventing the Westphalian system. Regardless of the justifications employed at the outset, military intervention, is now an established international practice. "Since 1989 there have been forty UN peacekeeping missions, only seven concerning interstate conflicts." (Ottaway \& Lacina: 2003; 74) The remaining 33 peace keeping missions have involved the intervention of the international community in the internal affairs of a state. The focus in this work is on the developments that occur after that intervention has taken place. 
The list of UN mandated international reconstruction efforts is ever growing, Afghanistan simply presents itself as one of the most recent on this list. Simon Chesterman, in his book You, the People; the United Nations, Transitional Administration and State Building, traces the evolution of this trend beginning in the time immediately following World War One with the League of Nations. $(2004 ; 12)$ The promotion of democracy has emerged within this international reconstruction trend as the preferable form of governance. (von Hippel: 2000; 95) The UN has become increasingly willing to classify events as 'threats to international peace and security' and therefore more willing to mandate intervention and state building missions. (Chesterman: 2004; 3) Listed among the most recent of these intervention and reconstruction missions are the ones in Somalia, Bosnia, Kosovo, East Timor, and the focus of this work, Afghanistan.

Post-intervention situations are also considered 'post conflict'. There is an important point about the nature of 'post conflict' that needs to be addressed here. The term 'post conflict' is often misleading as the situations deemed 'post conflict' by the international community, such as present day Afghanistan, are not peaceful and conflict free. 'Post conflict' has been described as a situation where "conflict has subsided to a greater or lesser degree, but is ongoing or recurring in some parts of the country." (Brinkerhoff: 2005 ; 4) Afghanistan provides a clear example of this trend with its growing levels of violence that marked the first six months of 2005 as the bloodiest since the 2001 invasion. (Synovitz: 2005, a) It is in this 'post conflict' time that the international community works beyond the mandates of 'peace keeping' into the realm of 'nation building'. 
Nation building, or state building has come to represent a very specific set of goals in recent years, particularly since the beginning of the 1990's. Amitai Etzioni argues that the phrase 'nation building' is used to describe three related tasks: "the unification of disparate ethnic groups; democratization; and economic reconstruction." $(2004 ; 2)$ The democratization aspect of nation building is often viewed as a way of achieving success in the unification of disparate groups and contributing greatly to economic reconstruction. It can be argued that democracy provides a forum of coexistence and cooperation between these factionalized entities. There is, as well, a diverse collection of scholarship devoted to the connection and interplay between economic development, liberalization, and democracy. Authors like Michael Mandelbaum, Benjamin R Barber and Fredrick A. Hayek all have published volumes on this subject. Simply put, perhaps over simply, emerging democracies and growing economies can work to support each other. "Today, nation building normally implies the attempt to create democratic and secure states" (von Hippel: 2000; 96)

How can this pattern of democracy promotion through nation building be explained? Marina Ottaway points out that "It is politically correct to equate state reconstruction with democracy building." (2002) What is it about democracy that makes it politically correct when working within formerly sovereign states to reconstruct stability and security? One explanation is the association of democracy with that of durable peace. (Call \& Cook: 2003; 135) It is true that democratic states tend not to wage war on other democratic states. Democratic states, however, do wage war against non democratic states surprisingly frequently for this association of democracy and a durable peace to have survived as well as it has. Although peace is preferable in many ways to its 
opposite, war, war has a force all its own. War can act to regenerate a floundering economy and bolster support for a leader. Democracies do not necessarily exist peacefully when it is in their interests (or leader's interests) to wage war.

The other, more forceful, explanation of the consistent promotion of democracy through the use of internationally led nation building is the emergence of democracy as a universal human right as developed in Thomas Franck's democratic norm thesis. (1995; 137) Gregory Fox echoes Franck's democratic norm arguing that "parties to the major human rights conventions have created an international law of participatory rights". $(2000 ; 90)$ Fox further states that international law is developing the notion of democratic entitlement; the view that "representative government, chosen in fair and periodic elections, is a human right of all citizens." $(2000 ; 180)$

The perception of a universal democratic entitlement along with the belief that promoting democracy is a way to promote peace and stability are two examples of the rationale behind the rise in international democracy promotion in 'post conflict' societies. In any instance of international intervention on humanitarian or security grounds the intervening forces are met with the obligation to establish some form of order. Without creating stability in its wake, any intervention would be a costly mistake, both in terms of capital and human lives. In his 1994 Agenda for Development then UN Secretary General, Boutros Boutros-Ghali, emphasized the importance of democratic governance as a part of 'good governance'. (Forsythe: 1997; 337) Democracy presents itself as the most appropriate choice. Democracy's moral authority rests in the premise that its laws are directed by those it governs. 
What of the contradiction 'imposed freedom'?

To engage in democracy promotion through international reconstruction is to engage in contradiction. 'Post conflict' societies do not develop democracies internally and spontaneously. As stated earlier, states classified as 'post conflict' are frequently still in conflict. In order for any peaceful form of governance to take root in these often turbulent situations, some military force is necessary. Marina Ottaway argues that if the international community does not want to leave a situation alone until it 'works itself out' than it "has to establish control through a military presence willing to use deadly force." (2002) But can this use of military might work to instil the fundamental freedoms of democracy? There is an essential contradiction between the desired ends, a selfdetermining democracy, and the use of military force to achieve these means. Chesterman outlines this same contradiction between the means of military might and the goal of establishing freedoms. He, however, cites the means as a "benevolent foreign autocracy". $(2004 ; 1)$

This friction stemming from force and imposition is unavoidable within the current 'post conflict' reconstruction practice. It is this point of contestation that leaves international reconstruction missions open to the critique of imperialism. Is there any such thing as the "benevolent foreign autocracy" that Chesterman identifies? I argue there is not. Intervention and the obligatory reconstruction that follows are immensely costly to the international community. Democracy takes time to develop and take root, especially in a society that has never functioned according to the governance structures that are identified as democratic. In order to establish the stability and security necessary for democracy, foreign interveners in the country must be willing to commit to a long 
term military and financial interest. The longer there is a foreign occupier, the more the situation resembles colonialism. (Packer: 2003) In the example of Afghanistan, 20000 Coalition forces, led by the American forces, and 11000 International Security Assistance Forces soldiers have been engaged in creating stability and security since late 2001. (Sedra \& Middlebrook: 2005) In addition to the military might working towards stability, the Afghan government has received approximately 10 billion US dollars in aid in the last two years. (Sedra \& Middlebrook: 2005) The reconstruction of a civil society and the construction of a legitimate democracy are long term and very expensive projects. The international community needs strong motivators in order to endorse a plan of action that will surely be so resource dependent. These motivators are foreign based interests in a 'post conflict' society and they are therefore unable to be completely benevolent.

The argument however persists that in order for reconstruction projects, such as the one underway in Afghanistan, to succeed in creating stable functioning democracies more intensive, longer term international involvement is necessary. Michael Ignatieff refers to this as 'humanitarian empire'. He supports the suspension of a state's autonomy in order to achieve democratic goals through imperial means. $(2003 ; 122,113)$ Although he acknowledges the contradiction in this procedure he believes that for cases such as Afghanistan, Bosnia and Kosovo the ends justifies the means. Ignatieff is not the only scholar who recognizes this contradiction. Ottaway and Lacina argue that international interventions, particularly those aimed at nation building, have some imperial characteristics. $(2003 ; 75)$ They point to the interventions of the $1990 \mathrm{~s}$ in which "international personnel aim to build democratic and stable political systems" thereby representing "an external imposition of a new political framework." (2003; 75) They do 
recognize the imperial characteristics present in these intervention and state building missions. However, they feel that the very different objectives, humanitarian and peace making, and the absence of creating "a blatantly discriminatory caste system", an essential element of imperial interventions, mean that the imperial characteristics are not sufficient to term the intervention imperial itself. (2003: 75)

The reality of internally led reconstruction is the need for greater international involvement in order to achieve the goals set out at the onset of these activities. Establishing a stable and just democratic system of governance is no small task. If the international community sets this as the reconstruction goal than much more (in terms of time, capital, armed forces and aid) is needed. Many mistakes in the last ten years of peace keeping and nation building involve doing too little or leaving too soon. (Durch: 2003; 206) Former Secretary General of the United Nations Boutros Boutros-Ghali observed, after the 1995 'failed' Somalia Operation that there were new challenges in 'post conflict' situations that required more intensive nation building efforts. (Chesterman: 2004; 2) Gordon Peake argues for the installment of an international trusteeship in the case of Afghanistan as the most effective method for reconstruction. $(2003 ; 190)$

Failing to achieve the goal of establishing a functioning democracy in a reconstruction mission is damaging to the legitimacy of that mission as well as the country. Requiring more invasive imposition, in terms of military force, in order for the instalment of not only a democratic system of governance but also the stability, freedoms and rule of law necessary for its sustainability and growth is imperialist. Can the 
international community be effective in bringing free and fair democracies through imperial means?

Every single empire in its official discourse has said that it is not like all the others, that its circumstances are special, that it has a mission to enlighten, civilise, bring order and democracy, and that it uses force only as a last resort. And, sadder still, there is always a chorus of willing intellectuals to say calming words about benign or altruistic empires. (Said: 2003)

There is still the problem of international reconstruction efforts that fail to establish a system of governance that can function effectively as a democracy. In fact, the number of internal reconstruction efforts that produced fully functioning democracies is very low. This of course depends on the definition of 'fully functioning democracy' employed and source examined. It is possible that the criterion examined is too stringent, that a democracy can not be expected to be fully functioning within twenty years. Realistically it is true that democracies need time to evolve, however if a system of governance that does not meet the criteria of a 'democracy' is being labelled 'democracy' the term may begin to loose its force. David Wippman posits East Timor as the only relative successful reconstruction, since the reconstruction of Germany and Japan in the aftermath of World War Two. (2004; 30) Although the level of success is debated East Timor provides an interesting case as it is one of the most intensive internationally led reconstruction efforts, in which the United Nations and the World Bank had a 'trusteeship' role. (Orford: 2003; 24) A trusteeship is the most invasive form of international aid in reconstruction, the relative success of East Timor therefore lends support to those who would suggest more invasive measures are necessary in the reconstruction of 'post conflict' societies. 
Despite the resemblance and shared characteristics of imperial actions, the governments being established in the 'post conflict' societies continue to encourage international involvement, both militarily and financially. Ashraf Ghani, the Afghan Transitional Authority's Finance Minister, made the pitch recently that Afghanistan is not a charity case but an investment in a stable Asia and therefore a stable global society. (2005) He argued that the state building project currently underway in Afghanistan is a long term project. He suggested that Afghanistan needs a minimum of ten years of continued international support. Ghani was trying to ensure the continued investment of the international community in Afghanistan for as long as possible. How does this desire for involvement on the part of 'post conflict' societies play into the contradiction of the imposition of freedom?

Through the discussion above there appears to be two basic paths available for internationally led democratic reconstruction in a post conflict society. Following intervention, impose as little as possible upon the 'post conflict' society, thereby leaving an incredibly weak state to attempt reconstruction on its own. This is undesirable as the international community in this scenario has disengaged from the 'post conflict' state. This disengagement essentially leaves the 'post conflict' country too weak to function effectively, thus resulting in further decomposition of state structures through corruption, inability to deliver services or the outbreak of civil war. The other scenario suggests the intensive involvement in reconstruction on the part of the international community, thus producing an imperial relationship between the 'post conflict' state and international community involved in its reconstruction. Equally undesirable, this scenario reproduces colonial relations between actors and the legitimacy of any democratic government 
developed is tainted through the manner in which it came to power in the first place. These two paths exemplify only two extremes. The middle point, international involvement and shared leadership between local and international actors, although not without its own contradictions, allows for the greatest legitimacy and security to coexist.

Although international missions engaged in reconstruction in 'post-conflict' societies often resemble acts of empire they can become easier to accept through a key concept in this work: legitimacy. "Legitimacy refers to the acceptance of a governing regime as correct, appropriate and/or right." (Brinkerhoff: 2005; 5)

Reconstructing legitimacy in post-conflict states involves expanding participation and inclusiveness, reducing inequities, creating accountability, combating corruption and introducing contestability (elections). Delivering services, which links to the effectiveness dimension is also important for establishing legitimacy; it demonstrates government willingness and capacity to respond to citizens' needs and demands. Further this category includes constitutional reforms, reestablishment of the rule of law and institutional design... (Brinkerhoff: $2005 ; 5)$

The implementation of democracy itself is a factor that often works to legitimate these missions. The concept here is that while the form of governance being established is to a greater or lesser extent imposed, it is a governance that the people of the country will assume control over through the mechanisms it possesses.

Legitimacy, of course, depends on perspective. Whether or not a state or system of governance is considered legitimate is viewed differently by internal and external observers. Democracy is a tool that aims at creating both national and international legitimacy. Since democracies are designed to ensure equalities, allow for political participation and make all citizens equally accountable for their actions under the law, they give the impression of carrying legitimacy in and of themselves. Democracy is 
widely held to be the governance system with the strongest form of legitimacy around the world. (UNDP: 2002) Therefore democracy acts not only to create the internal legitimacy necessary for reconstruction but also the external legitimacy necessary for the sanctioning of that reconstruction.

The international sanctions themselves also contribute to increased international legitimacy for reconstruction. Were a single country to act alone in the process of intervention and reconstruction the actions would be much more akin to those of empire. "The UN is uniquely equipped with the legitimacy, experience, coordinating ability, and logistics mechanisms to work in postconflict settings..." (Durch: 2003; 196) As an international body, governed by the international laws that it worked to establish, the United Nations has a unique role in reconstruction. "UN resolutions provide the United States not only with helpful allies but also with international legitimacy" (Pei \& Kasper: 2003 ; 2) It has the internationally based legitimacy to act, or to sanction other's actions, in 'post conflict' societies granted through its multi national Security Council. The United Nations is effective at promoting international legitimacy but what of internal legitimacy? In an attempt to ensure higher level of internal legitimacy in 'post conflict' states undergoing reconstruction there has been an increased interest in local ownership of the process. (Chesterman: 2004; 242)

\section{The Arguments For and Against Local Ownership:}

Local ownership, like the other elements of internationally led reconstruction, does not exist clear of complications. Maximizing local ownership in reconstruction is an important and strategic move. Local ownership carries the power to instil internal 
legitimacy to a reconstruction effort. The international community must continue to share in the ownership of the reconstruction process. The local institutions in a "post conflict' society will not have the capacity to deliver the security, services and rule of law that any emerging democracy needs. Ghani rightly argues that increasing the amount of local ownership in the Afghan situation must not be a mechanism for the international actors to withdraw when the situation is still fragile. (2005) Having aided the Afghan government through the transition period into its current democratically elected status does not mean that the work of the international community is done. Were the international forces and support staff to pack up and leave Afghanistan today the emerging democracy there would not be able to survive. Furthermore, Ghani argues, in such a case the international community would be able to deny responsibility for the failure of the state as local ownership was in place and therefore responsible. Internal reconstruction efforts must be joint efforts of the local population and the international community. They must continue to be joint efforts until the local institutions have built the capacity to govern.

Local ownership provides great potential for increased legitimacy in the reconstruction process. This legitimacy is not, however, absolute. As stated earlier, legitimacy "refers to the acceptance of a governing regime as correct, appropriate and/or right." (Brinkerhoff: 2005; 5) This requirement of 'acceptance' by the national community of the government as 'correct, appropriate and/or right' is more likely when there is local ownership involved but that local ownership does not necessarily result in the acceptance of a government as correct. 
One issue that comes up in the case of Afghanistan is: which local owners are involved and how were they selected? The Bonn conference is referred to as a 'conference of victors' and the Afghan Internal Administration and Afghan Transitional Authorities that evolved through the process are widely acknowledged as unrepresentative of the wider Afghan population. (Johnson \& Leslie: 2002; 862) These three institutional stages, along with the development of the current Afghan government, all contributed to the eventual outcome of the democratic elections, establishing President Karzai in a position of power and greater access to campaigning resources compared to his co-candidates. This process had the effect of greatly influencing the outcome of the presidential election.

Even though local ownership works against the critique of imperialism, it can still be a party to imperial acts. In order for local ownership to emerge in internationally led reconstruction efforts local actors must be selected to act on behalf of their communities. The engagement in Afghanistan of leaders from various religious, ethnic and Northern Alliance militia in the political process while the Taliban leaders, who had ruled fairly effectively if brutally for at least five years, were shut out of the process, shows a clear and agenda, the eradication of the Taliban movement, on the part of the international community orchestrating the process. One potential reason for the exclusion of the Taliban could have been their documented human rights abuses. However many of the warlords who were included also fall into this category.

Fukuyama argues that local power brokers during reconstruction are motivated to create institutions that protect their own power, thus entrenching the status quo. (2005; 86) A clear example of this trend is the inclusion of warlords in the political process in 
Afghanistan. The political process could not have gotten underway as quickly as it did (a few short months after the US led invasion) without the inclusion of these warlords, yet their inclusion has damaged not only the legitimacy of the developing democracy. It also solidified their grasp on power through new political means. (Sedra \& Middlebrook: 2005) Local ownership often also leads to corruption as these are countries with shattered economies; no one is paid well enough to offset the temptation of corruption. (Fukuyama: 2005 ; 86) The potential for local ownership to entrench the status quo, enable corruption and potentially advance imperial objectives clearly presents an argument for caution in the move towards local ownership. These negative potentialities for local ownership do not, however, overshadow the positive ones.

According to Fukuyama, there are three rationales for maximizing local ownership. Firstly, there is a difficulty in 'post conflict' situations to sustain international interest. (2005; 87) International reconstruction, as described above, is costly and complicated. The waning of the international interest should ideally not factor into the discussion of local ownership, however the reality shows that there is a shrinking appetite for this type of international reconstruction. (Etzioni: 2004; 16, Ottaway: 2002) Fukuyama's second reason for promoting local ownership is that outsiders do not necessarily know how to govern. $(2005 ; 87)$ This simple critique states the obvious observation that is all too often passed over. Marina Ottaway argues the international community "has neither the will nor the way" in terms of building nations. (2002) Thirdly, on Fukuyama's list, is the most forceful reason to promote local ownership of all: early local ownership generates a better chance of sustained local institutions. (2005; 
87) Early local ownership is able to generate that chance through the locally created perception of legitimacy of the local government.

Afghanistan presents itself as an interesting case both for and against local ownership. By classifying Afghanistan as 'post conflict' the UN and Karzai government were able to justify putting the Afghan government into the driver's seat very early in the reconstruction effort. (Donini: 2004; 26) However, the conflict in Afghanistan is not over. As shown in chapter three, Afghanistan is not conflict free. The model that the United Nations attempted to use in Afghanistan, to effectively promote and increase local ownership, is called the 'light footprint' model. The early establishment of Afghan governance institutions, including elections and a constitution, promotes the perception of great local ownership in the process. "Not only is the 'light footprint' that was advocated from the beginning by Ambassador Brahimi being trampled but the acknowledged need for 'Afghan ownership' is being called into question by lack of consultation" (Johnson \& Leslie: $2002 ; 872$ ) The UN can not bring peace and stability alone, it needs to incorporate and engage local civil actors. (Bell \& Tousignant: 2001)

Afghan ownership of the reconstruction process is critical for success. A solution can not be imposed from abroad. (del Castillo: 2003; 134) The balancing act necessary to counter the negative potential of local ownership and yet still promote local legitimacy needed for sustainable governance is a difficult but necessary one. Local ownership is desirable and necessary in cases of internationally led reconstruction. The capacities of emerging local governments must not, however, be overestimated. 


\section{Conclusion:}

Democracy is promoted as a universal human right. It is arguably legitimate in and of itself. The international community that develops democracies in the wake of interventions has no viable option other than democracy. It has been established through international law as a universal human right. The inherent moral authority within democracy does not grant moral authority to the means in which democracy is implemented in states post intervention. An inseparable aspect of democracy is the protection of freedoms such as the freedom of speech, mobility or association. The act of reconstructing a civil society in a 'post conflict' state by outside actors is inherently an imposition. There is an uneasy contradiction in the fundamental freedom of democracy being imposed in a 'post conflict' state. This contradiction is compounded by the argument that in order for the reconstruction to be effective the international community needs to be more involved for a longer period of time in the state it seeks to instil with democracy.

When undertaking internationally led reconstruction efforts it is impossible to avoid being engaged in these contradictions. The international community can act to support local ownership, establish a democracy complete with the rule of law and fundamental freedoms and yet be guilty of imperialism. There is no way around this intensely problematic nature of reconstruction. The international community can only decide how much or how little imposition, financial support, military support, and involvement it is willing to contribute to the reconstruction. In making this decision the international community has a responsibility to be both more honest about what it is 
willing and able to undertake and then set goals based on these realities. Contradictions are not sufficient reason to end developmental aid to 'post conflict' societies. They are points for further attention and negotiations. In this way the international community will be better positioned to assist in the development of future 'post conflict' societies. 


\section{Conclusion}

This thesis dealt with the themes of legitimacy, democracy, and international reconstruction efforts. These are all intertwined in the case study of Afghanistan in the post 2001 intervention era. Legitimacy was shown to be different things to different people. International actors gain their legitimacy through acting according to international laws and sanctions. Local actors gain their legitimacy through the representation of their communities, through election processes and through the ability to deliver results, such as stability and security to the population at large.

Democracy is often viewed as inherently legitimate. It is, through its institutions, responsible to the people it governs. Democracy applies freedoms and restrictions, laws and obligations equally among its citizens. This gives it a moral authority. Increasingly there is an international recognition of not only the moral authority and legitimacy inherent in democracy but also the right of individuals to be governed democratically. Established through international law, the democratic right to political participation of all citizens is arguably a universal human right.

Not all systems of governance labelled 'democracy' are in fact genuine democracies. The legitimacy ascribed to democratic status can be manipulated and used in situations where the system of government falls short of democratic standards of equality, the access to political participation and rule of law. In these situations, where a system of governance is defined as 'democratic' but actually falls far short of the democratic model, what develops is often more damaging to the society than an outright authoritarian regime. Neither ballot box elections nor democratic institutions on their

own guarantee democracies. In these situations, the lack of substantive democratic 
entitlements works to undermine not only the false democracy but also any future democratic initiative.

The international community that becomes involved in the development of democracy in 'post conflict' societies has the potential to either aid in the establishment of thin, low intensity democracies, or, engage in the more onerous job of establishing fully functioning democracies. Afghanistan is an example of a situation in which the international community is currently involved in the development of democratic governance. This development is immensely challenging. Afghanistan has a lengthy history of problematic foreign intervention and its current status as a 'post conflict' country is inaccurate. Afghan history reveals an ongoing story of resistance to foreign imposition and a fractured society. The history of international involvement in Afghanistan is a negative one and clearly explains the resistance to foreign imposition. Afghanistan has been used as a pawn or bargaining piece, a coveted trade route, a sought after expansion of empire and a site of the 'Cold War'. Fractionalized Afghan society has its roots in a country where central authority has traditionally been weak and therefore local, community-level leadership became the most important source of leadership.

The international community is, however, obligated to aid Afghanistan in its reconstruction. The legacy of international interference is sufficient to imply this obligation but even more pressing is the American led invasion of 2001. The invasion sought to topple the Taliban regime and this goal was easily managed. Once in Afghanistan, having created more destruction and instability the international community 
that was involved in the invasion had an obligation to aid in the reconstruction of peace and stability.

This obligation to aid in reconstruction puts the international community in the difficult position of leadership. The governance model that the international community and local Afghan elites appear to be building is a liberal representative democracy. This government has established many of the institutions necessary for a democracy, however upon closer scrutiny they fall short of meeting the necessary requirements. Expecting a fully formed democracy to have emerged in the last four years out of the political upheaval of 2001 Afghanistan is entirely unrealistic. Unfortunately the actors involved, both Afghan and international, present the picture of Afghan democracy as completed upon the last elections. This is a dangerous ploy as it allows for the undemocratic realities of corruption, instability and warlord influence to go on unchecked and therefore undermine the democratic progresses that have been made.

The international community's largest stumbling block however is the criticism of imperialism. The international community is involved in the imposition of a democratic form of governance in the reconstruction of 'post conflict' states. Democracy, inherently self legitimating, is involved in the promotion of certain freedoms. The imposition of this freedom ensuring system of governance places the international community in a contradiction. This contradiction is necessarily involved in any internationally led reconstruction effort. It is, what I term, a necessary weakness. The international community is obligated to aid in reconstruction. Unfortunately, internationally led reconstruction is subject to the critique, and most often guilty of, some form of imperialism. The involvement of local actors in the reconstruction process work to lessen 
the imperial nature of the reconstruction. A balance must be achieved in this scenario that acknowledges the imposition of democracy by the international community. 


\section{$\underline{\text { Resources List }}$}

Ahmed, Samin, "Warlords, Drugs, Democracy," in The World Today, pp. 15-17, May, 2004.

Allan, Nigel J. R. "Rethinking Governance in Afghanistan," in Journal of International Affairs, Vol. 56, No. 1, pp. 193-202, 2003.

Agreement on the Provisional Arrangements in Afghanistan Pending the ReEstablishment of Permanent Government Institutions, 2001, (the Bonn Accords) adopted December 5, 2001.

$<$ http://www.afghangovernment.com/AfghanAgreementBonn.htm $>$ (cited November, 2004).

Amani, Wahidullah, "Parties Fume On The Sidelines," (Institute for War and Peace Reporting) Afghan News Compiled by the Embassy of Afghanistan in Canada, updated September 18, 2005, <www.afghanemb-canada.net> (cited September 19, 2005).

Amnesty International, "Open Letter to Participants in the International Conference on Reconstruction Assistance to Afghanistan," updated January 16, 2002, <http://web.amnesty.org/library/index/ENGASA110022002> (cited January, 2005).

Amnesty International, "Afghanistan, Human Rights Concerns: A Message From NGOs To Donors," updated September, 2002, $<$ http://web.amnesty.org/library.index/ENGASA110162002> (cited January, 2005).

Amnesty International, "Afghanistan: Re-Establishing the Rule of Law," updated October, 2003, <http://web.amnesty.org/library/index/ENGASA110212003> (cited January, 2005).

Amnesty International, "Open Letter to Participants in the International Conference on Reconstruction Assistance of Afghanistan," updated March 26, 2004, <http://web.amnesty.org/library/index/ENGASA110062004> (cited December, 2004).

Amnesty International, "Public Statement: Afghanistan: Amnesty International Condems the Disregard for Human Life," updated May 13, 2004, <http://web.amnesty.org/library/Index/ENGASA1 10082004> (cited January, 2005). 
Anderson, Kenneth, "Humanitarian Inviolability in Crisis: The Meaning of Impartiality and Neutrality for UN and NGO Agencies Following the 2003-2004 Afghanistan and Iraq Conflicts" in Harvard Human Rights Journal, Vol. 17, Spring, 2004.

Anwar, Raja, The Tragedy of Afghanistan, Verso; London, UK; 1998.

Armitage, Richard L. "Prepared Statement: Hearing on Accomplishments in Afghanistan," Committee on International Relations; U.S. House of Representatives, Washington, D.C. updated September 29, 2004, $<\mathrm{http}: / /$ wwwa.house.gov/internatioanl_relations/108/arm092904.htm> (cited July, 2005).

BBC (British Broadcasting Company), "Timeline: Afghanistan, a Chronology of Key Events, updated September 20, 2005, $<$ http://news.bbc.co.uk/1/hi/world/south_asia/1162108.stm> (cited October, 2004).

Barakat, Sultan, "Setting the Scene for Afghanistan's Reconstruction: The Challenges and Critical Dilemmas," in Third World Quarterly, Vol. 23, No. 5, pp 801-816, 2002.

Barakat, Sultan \& Margaret Chard, "Theories, Rhetoric and Practice: Recovering the Capacities of War-Torn Societies," in Third World Quarterly, Vol. 23, No. 5, pp 817-835, 2002.

Barfield, Thomas J. "Problems in Establishing Legitimacy in Afghanistan," in Iranian Studies, Vol. 37, No. 2, June, 2004.

Barfield, Thomas J. "First Steps: The Afghan Elections," in Current History, pp. 125-130, March, 2005.

Barnes, Samuel H. "The Contribution of Democracy to Rebuilding Postconflict Societies," in The American Journal of International Law, Vol. 95, January, 2001.

Bastian, Sunil \& Robin Luckham, "Can Democracy be Designed?" in Can Democracy Be Designed? The Politics of Institutional Choice in Conflict Torn Societies, Sunil Bastian \& Robin Luckham Editors, Zed Books; New York \& London; 2003, pp. 1-13.

Bauer, Joanne R. \& Daniel A. Bell eds. "Silence Breaking: The Women's Dimension of the Human Rights Box," in the Carnegie Council on Ethics and International Affairs Human Rights Dialogue, Series 2, No. 3, pp 1-2, Summer, 2000. 
Beck, Ulrich, "Make Law, Not War," (Translated from German in Der Spiegel, 2003) updated 2003, <http://portland.indymedia.org/en/2003/01/41880.shtml> (cited September, 2004).

Bell, Peter D. \& Guy Tousignant, "Getting Beyond New York: Reforming Peacekeeping in the Field," in World Policy Journal, Vol. 18, Issue 3, pp. 41-47, 2001.

Belloni, Roberto, "Civil Society and Peacebuilding in Bosnia and Herzegovinia," in the Journal of Peace Research, Vol. 38, No. 2, pp. 163-180, 2001.

Benholz, Peter, "Necessary and Sufficient Conditions for a Viable Democracy," in Understanding Democracy; Economic and Political Perspectives, Albert Breton, Gianluigi Galeotti, Pierre Salmon and Ronald Wintrobe eds. Cambridge University Press; Cambridge, United Kingdom; 1997.

Bermeo, Nancy, "What the Democratization Litreature Says—or Doesn't SayAbout Postwar Democratization," in Global Governance, Vol 9. Issue 2, pp. 159$178,2003$.

Beveridge, Fiona \& Jo Shaw, "Introduction: Mainstreaming Gender in European Public Policy," in Feminist Legal Studies, Vol 10, pp. 209-212, 2002.

Blaug, Ricardo, “Engineering Democracy," in Political Studies, Vol. 50, pp. 102$116,2002$.

Bloomberg News, "Clinton: Afghanistan is a bigger threat," Afghan News Compiled by the Embassy of Afghanistan in Canada, updated September 20, 2005, <www.afghanemb-canada.net> (cited September 21, 2005).

Brinkerhoff, Derick W. "Rebuilding Governance in Failed States and PostConflict Societies: Core Concepts and Cross-Cutting Themes," in Public Administration and Development, Vol. 25, pp. 3-4, 2005.

Brooks, Geraldine, Nine Parts of Desire; The Hidden World of Islamic Women, Anchor Books; New York, NY; 1995.

Burnell, Peter, "Political Strategies of External Support for Democratization," in Foreign Policy Analysis, Vol. 1, Issue 3, 2005.

Bush, George W. "President Bush Thanks the World Coalition for Anti-Terrorism Efforts," updated March 11, 2002, <http://www.state.gov/coalition/cr/rm/2002/8729.htm> (cited November, 2004).

Call, Charles T. \& Susan E. Cook, "Introduction: Postconflict Peacebuilding and Democratization," in Global Governance, Vol. 9 pp. 135-139, 2003. 
Canada, Government of, "Canada-Afghanistan Relations," $<$ http://www.canadaafghanistan.gc.ca> (cited November, 2004).

Canadian Armed Forces, "Current CF Contributions to UN Peace Support Operations," updated January, 2005,

$<$ http://www.forces.gc.ca/site/operations/index_e.asp> (cited February 17, 2005).

Carapico, Shelia, "NGOs, INGOs, GO-NGOs and DO-NGOs; Making Sense of Non-Governmental Organizations," in Middle East Report, Vol. 214, Spring, 2000. $<$ http://www.merip.org/mer/mer214/214_carapicio.html $>$ (cited June, 2005).

Carter, April \& Geoffrey Stokes eds. Democratic Theory Today: Challenges for the $21^{\text {st }}$ Century; Polity Press; Malden, MA; 2002.

Charlesworth, Hilary \& Christine Chinkin, "Sex, Gender, and September 11," in The American Journal of International Law, Vol. 96, No. 3, pp. 600-605, 2002.

Charlesworth, Hilary \& Mary Wood, "Women and Human Rights in the Rebuilding of East Timor," in the Nordic Journal of International Law, Vol. 71 pp. 325-348, 2002.

Cheragh, (Afghan Newspaper) "It Is Not Wise To Postpone Parliamentary Elections Again," updated January 31, 2005, $<$ http://proxy.library.carleton.ca:17814/intranet/cgi/rpresent?STYLE=739318018 \&PRESENT=DB=985,AN=202400438,FM=9,SEARCH=MD.GenericSearch $>$ (cited March, 2005).

Chesterman, Simon, Just War or Just Peace? Humanitarian Intervention and International Law, Oxford University Press; Oxford, England; 2001.

Chesterman, Simon, "Tiptoeing Through Afghanistan: The Future of UN StateBuilding," an International Peace Academy Report, updated September, 2002, $<$ www.ipacademy.org> (cited November, 2004).

Chesterman, Simon, You the People; The United Nations, Transitional Administration, and State Building, Oxford University Press; New York, New York; 2004.

Chesterman, Simon, "From Kabul to Baghdad: Unfinished Business" $<$ http://www.inthenationalinterest.com/articles/Vol1Issue8/Vol1Issue8Chesterma n.html $>$ (cited Feb 17, 2005).

Chopra, Jarat, "Divided Rule," in World Today, Vol. 57, No. 1, pp. 13-15, January, 2001. 
Commettie to Protect Journalists, "Press Release," updated October 3, 2005, <http://www.cpj.org/index.html> (cited August, 2005).

Constitution of the Islamic Republic of Afghanistan, 2004, adopted January 4, 2004, <http://www.oefre.unibe.ch/law/icl/af00000_html> (cited November 2004).

Cooney, Daniel, "21 Afghan Election Candidates Disqualified," The New York Times, updated September 12, 2005,

$<$ http://www.boston.com/news/world/asia/articles/2005/09/12/21_afghan_election _candidates_disqualified $>$ (cited September 12, 2005).

Cooney, Daniel, "Vote-Counting Centers Get Afghan Ballots - Trucks, Helicopters and Donkeys Carry Afghan Ballots to Counting Centers Across Country," (Associated Press) Afghan News Compiled by the Embassy of Afghanistan in Canada, updated September 20, 2005, <www.afghanembcanada.net $>$ (cited September 21, 2005).

Crotty, William ed. Democratic Development and Political Terrorism; the Global Perspective, Northeastern University Press; Boston, MA; 2005.

Dahl, Robert A. "Can International Organizations be Democratic? A Skeptic's View," in The Global Transformation Reader; an Introduction to the Globalization Debate, $2^{\text {nd }}$ ed. David Held \& Anthony McGrew eds. Polity Press; Cambridge, UK; 2003 (530-541).

del Castillo, Garciana, "Afghanistan: The Way Forward," in Global Governance; Vol. 9, pp. 153-157, 2003.

Dickerson, Mark O., Thomas Flanagan \& Neil Nevitte Introductory Readings in Government and Politics, $4^{\text {th }}$ edition. Nelson Canada; Scarborough, ON; 1995.

Dodge, Toby Inventing Iraq; The Failure of Nation Building and a History Denied, Columbia University Press; New York, New York; 2003.

Donini, Antonio, "An Elusive Quest: Integration in the Response to the Afghan Crisis," in Ethics and International Affairs, Vol. 18, No. 2, pp. 21-27, 2004.

Donnelly, Jack, "Human Rights, Democracy and Development," in Human Rights Quarterly, Vol. 21, No. 3, pp. 608-632, 1999.

Dorronsoro, Gilles, Revolution Unending; Afghanistan: 1979 to the Present, C. Hurst \& Co. (Publishers) Ltd.; London, United Kingdom; 2005. 
Dupree, Nancy Hatch, "Cultural heritage and national identity in Afghanistan," in Third World Quarterly, Vol. 23, No. 5, pp. 977-989, 2002.

Durch, William J. "Picking Up the Peaces: The UN's Evolving Postconflict Roles," in The Washington Quarterly, Vol. 26, No. 4, pp. 195-210, 2003.

Economist Newspaper ltd. (the) "Reconstructing Kosovo," March 18, 2000, US Edition.

The Electoral Law, 2004, The Islamic Republic of Afghanistan, adopted May 12, 2004.

Emadi, Hafizullah, "Nation Building in Afghanistan," in Contemporary Review, Vol. 283, pp. 148-155, Summer, 2003.

Entekhabi-Fard, Camelia, "Afghanistan's Braces for Chaotic and Potentially Violent Parliamentary Vote" Eurasia Insight, updated September 15, 2005, $<$ http://www.eurasianet.org/departments/insights/articles $>$ (cited September 20, 2005).

Eurasia Insights "Human Rights Watch Report Documents War Crimes, Reccomends Prosecutions" updated July 12, 2005

$<\mathrm{http}$ //Www.eurasianet.org/departments/insights.articles $>$ (cited September 20, 2005).

Eutekhabi-Fard, Camelia \& Claudio Franco, "Afghanistan Parlimentary Election Turnout Lower than Expected" Eurasia Insight, updated September 19, 2005, $<$ http://www.eurasianet.org/departments/insight/articles/eav091905.shtml $>$ (cited on September 20, 2005).

Etzioni, Amitai, “A self-restrained approach to nation-building by foreign powers," in International Affairs, Vol. 80, No. 1, pp. 1-17, 2004.

Ewans, Martin, Afghanistan; a New History, RoutledgeCurzon; London, England; 2002.

Ewelukwa, Uche U. \& Albaqir A. Mukhtar, "Working Within Nigeria's Sharia Courts," in Carnegie Council on Ethics and International Affairs Human Rights Dialogue, Series 2, No. 10, Fall, 2003.

Falk, Richard A. The Declining World Order; Americas Imperial Geopolitics, Routledge; New York and London; 2004.

Ferguson, James, "The Reconstruction of Afghanistan: From War to Democracy?" (The Department of International Relations, FHSS, Bond 
University, Queensland Australia) updated 2004, <http://www.internationalrelations.com/wbeurasua/WBEA-2004-Lec10.htm > (cited March 26, 2005).

Firouz, Caren, "Afghan election count under way," (BBC) Afghan News Compiled by the Embassy of Afghanistan in Canada, updated September 20, 2005, <www.afghanemb-canada.net> (cited September 21, 2005).

Fletcher, Arnold, Afghanistan; Highway of Conquest, Cornell University Press; Ithaca, New York; 1965.

Flournoy, Michele \& Michael Pan, "Dealing with Demons: Justice and Reconciliation," in The Washington Quarterly, Vol. 25, No. 4, pp. 111-123, 2002.

Forst, Rainer, "The Basic Right to Justification: Toward a Constructivist Conception of Human Rights," in Constellations, Vol. 6, No. 1, 1999.

Forsythe, David P. "The United Nations, Human Rights, and Development," in Human Rights Quarterly, Vol. 19, No. 2, pp. 334-349, 1997.

Fox, Gregory \& Brad R. Roth eds. Democratic Governance and International Law, Cambridge University Press; Cambridge, United Kingdom, 2000.

Fox, Gregory, "The Right to Political Participation in International Law" in Democratic Governance and International Law. Gregory Fox \& Brad R. Roth Editors, Cambridge University Press; Cambridge, United Kingdom, 2000, pp. 4890.

Fox, Gregory H. "International Law and the Entitlement to Democracy After War," in Global Governance, Vol. 9, pp. 179-197, 2003.

Franck, Thomas M. "Legitimacy in the International System," in American Journal International Law, Vol. 82, October, 1988.

Franck, Thomas M. "The Emerging Right to Democratic Governance," in the American Journal International Law, Vol. 86, January, 1992.

Franck, Thomas M. Fairness in International Law and Institutions, Oxford University Press; New York, New York; 1995.

Franck, Thomas M. The Empowered Self; Law and Society in the Age of Individualism, Oxford University Press; New York, New York; 1999.

Freeman, Christopher P. "Dissonant Discourse: Forging Islamist States through Secular Models - The Case of Afghanistan" in Cambridge Review of International Affairs, Vol. 15, No. 3, 2002. 
Friel, Terry, "Bullets, Ballots and Burqas As Afghans Eagerly Vote" (Reuters) Afghan News Compiled by the Embassy of Afghanistan in Canada, updated September 18, 2005, <www.afghanemb-canada.net> (cited September 19, 2005).

Fukuyama, Francis, "The End of History?" in the National Interest, Summer, 1989. <http://www.wesjones.com/eoh.htm> (cited June, 2005).

Fukuyama, Francis, "The Imperative of State-Building," in Journal of Democracy, Vol. 15, No. 2, 2004.

Fukuyama, Francis, “"Stateness" First," in Journal of Democracy, Vol. 16, No. 1, pp. 84-88, 2005.

Gall, Carlotta \& Somini Seugupta, "United Nations Observers Report Peaceful Electionns," (New York Times) Afghan News Compiled by the Embassy of Afghanistan in Canada, updated September 20, 2005, <www.afghanembcanada.net> (cited September 21, 2005).

Gannon, Kathy, "Afghanistan Unbound," in Foreign Affairs Vol. 83, Issue 3, pp. 35-46, 2004.

Geislerova, Marketa, "Summary Report from the Roundtable on Afghanistan: Governance Scenarios and Canadian Policy Options," Canadian Center for Foreign Policy Development, Department of Foreign Affairs and International Trade, October 12, 2001.

Ghani, Ashraf, "Bonn and Beyond," Lecture in South Asian Seminar Series held October 21, 2005, Ottawa.

Gills, Barry, Joel Rocamora \& Richard Wilson, editors, Low Intensity Democracy; Political Power in the New World Order, Pluto Press; London, England; 1993.

Gladstone, Cary, Afghanistan; History, Issues, Bibliography, Nova Books; Huntington, New York; 2001.

Goodhand, Jonathan, "Aiding violence or building peace? The role of international aid in Afghanistan," in Third World Quarterly, Vol. 23, No. 5, pp. $837-859,2002$.

Goodson, Larry, "Afghanistan's Long Road to Reconstruction," in Journal of Democracy, Vol. 14, No. 1, pp. 82-99, January, 2003.

Goodson, Larry P. "Afghanistan in 2004; Electoral Progress and an Opium Boom," in Asian Survey, Vol. 45, Issue 1, pp. 88-97, 2005. 
Goodson, Larry, "Bullets, Ballots and Poppies in Afghanistan," in Journal of Democracy, Vol. 16, No. 1, pp. 24-38, 2005.

Gulzad, Zalmay A. External Influences and the Development of the Afghan State in the Nineteenth Century, Peter Lang Publishing, Inc; New York, New York; 1994.

Gunder Frank, Andre, "Marketing Democracy in an Undemocratic Market," in Low Intensity Democracy: Political Power in the New World Order, eds. Barry Gills, Joel Rocamora \& Richard Wilson: Pluto Press; London, England; 1993.

Gutterman, Steve, "Afghanistan Holds Legislative Elections," (Associated Press) Afghan News Compiled by the Embassy of Afghanistan in Canada, updated September 18, 2005, <www.afghanemb-canada.net> (cited September 19, 2005).

Hafner-Burton Emilie \& Mark A Pollack, "Gender Mainstreaming and Global Governance," Feminist Legal Studies, Vol. 10, pp. 285-298, 2002.

Hagen, Jonas, "Afghanistan One Year Later: The General Assembly Debates the Country's Reconstruction," UN Chronicle Vol. 40, No. 4, 2002.

Hattori, Tomohisa, "Giving as a Mechanism of Consent: International Aid Organizations and the Ethical Hegemony of Capitalism," in International Relations, Vol. 17, No. 2, pp. 153-173, 2003.

Held, David, Democracy and the Global Order; From Modern State to Cosmopolitan Governance, Stanford University Press; Stanford, California; 1995.

Held, David, Models of Democracy, $2^{\text {nd }}$ ed. Stanford University Press; Stanford, California; 1996.

Hobsbawm, Eric, J. "Spreading Democracy," in Foreign Policy, September/October 2004.

Huges, Chris, "We've Had Years Of Men Running Afghanistan Time To Give A Woman A Chance; Voters Who Snubbed Warlords," Afghan News Compiled by the Embassy of Afghanistan in Canada, updated September 20, 2005, $<$ www.afghanemb-canada.net> (cited September 21, 2005).

Human Rights Watch, "The Rule of the Gun; Human Rights Abuses and Political Repression in the Run-up to Afghanistan's Presidential Election," A Human Rights Watch Briefing Paper, September 2004.

Human Rights Watch, "Campaign Against Fear; Women's Participation in Afghanistan's 2005 Elections," updated August 2005, 
$<$ http://hrw.org/backgrounder/wrd/afghanistan0805/4.htm> (cited September 24, 2005).

Human Rights Watch, "Afghanistan: Protect Women Candidates; Boost Security Measures and Complaint Procedures as Campaign Launches," updated August 17, 2005, <http://hrw.org/english/docs/2005/08/16/afghan11633.htm > (cited September 15, 2005).

Human Rights Watch, "Afghanistan on the Eve of Parliamentary and Provincial Elections," updated September 2005, $<$ http://hrw.org/backgrounder/asia/afghanistan0905/index.htm $>$ (cited September 24, 2005).

Hutchinson, A.C. \& P. Monahan, "Democracy and the Rule of Law," in Introduction to Public Law; Readings on the State, The Administrative Process, and Basic Values, $4^{\text {th }}$ ed. Edited by David W. Elliott \& Rosemary E. Warskett: Captus Press Inc.; North York, ON; 1999.

Hyland, Julie, "Report Estimates Afghan Deaths Exceeds Twin Towers Figure," updated December 22, 2001, <http://www.wsws.org/articles/2001/dec2001/casd22.shtml > (cited December 2, 2005).

Hyman, Anthony, "Nationalism in Afghanistan," in International Journal of Middle East Studies Vol. 34, pp. 229-315, 2002.

Ignatieff, Michael, "The American Empire; The Burden," in the New York Times, January 5, 2003.

Ignatieff, Michael, Empire Lite: Nation Building in Bosnia, Kosovo and Afghanistan, Penguin Canada; Toronto, Canada; 2003.

Ingalls, Jim \& Sonali Kolhatkar, "Afghan Elections: U.S. Solution to a U.S. Problem," Foreign Policy in Focus; Silver City NM: Interhemispheric Resource Center, October, 2004.

Jackson, Paul, "Warlords as Alternative Forms of Governance," in Small Wars and Insurgencies, Vol. 14, No. 2, pp. 131-150, 2003.

Jardine, Matthew, "East Timor: Up From Ground Zero," in In These Times, updated October 16, 2000, <http://www.etan.org/et2000c/october/1-8/16up.htm> (cited June, 2005).

Jawad, Said Tayeb, "The U.S.-Afghan Partnership," The National Interest (Pakistan), updated June 9, $2004<\mathrm{http}: / /$ www.embasyof afghanistan.org/main/bios/Publication/HTML/Art060904ITNI.htm> (cited December, 2004). 
Jefferson, LaShawn R. "Refusing to Go Away: Strategies of the Women's Rights Movement," in Carnegie Council on Ethics and International Affairs Human Rights Dialogue, Series 2, No.10, Fall, 2003.

JEMB, "JEMB Certifies All Final Result for Wolesi Jirga and Provincial Council Elections" (Press Release) updated November 12, 2005, <www.jemb.org> (cited November 26, 2005).

Jennings, Ray Salvatore, "The Road Ahead; Lessons in Nation Building from Japan, Germany and Afghanistan for Postwar Iraq," (United States Institute of Peace) Peaceworks No.49, updated April, 2003, $<\mathrm{http}$ ///www.usip.org/pubs/peaceworks/pwks49.pdf> (cited December, 2004).

Johnson, Chris \& Joylon Leslie, "Afghans have their memories: a reflection on the recent experience of assistance in Afghanistan," in Third World Quarterly, Vol. 23, No. 5, pp. 861-874, 2002.

Karzai, Hamid, "Foreword," in the Afghanistan: National Human Development Report, 2004; Security With a Human Face; Challenges and Responsibilities, $<$ http://www.undp.org.af/summary\%2004\%final\%20PDF.pdf $>$ (cited March 25, 2005).

Katzman, Kenneth, "Afghanistan: Presidential and Parliamentary Elections," CRS Report for Congress, updated April 8, 2005 (Order Code RS21922).

Kennedy, David, "Boundaries in the Field of Human Rights: the International Human Rights Movement: Part of the Problem?" in The Harvard Human Rights Journal, Vol. 15, Spring, 2002.

Khalilzad, Zalmay \& Daniel Byman, "Afghanistan: The Consolidation of a Rogue State," in The Washington Quarterly, Vol. 23, No. 1, pp. 65-78, 2000.

Khan, Mujeeb R. "Islamic and Western Worlds: The End of History or Clash of Civilizations," in The New Crusades; Constructing the Muslim Enemy, Edited by Emran Qureshi \& Michael A. Sells, Columbia University Press; New York, New York; 2003, pp. 170-201.

Klass, Rosanne editor, Afghanistan; The Great Game Revisited, Revised Edition, Freedom House; MD, USA; 1990.

Kohi, Abdol Ali, "The Government Politicians After the Election," (Kabul Mojahed in Dari) updated October 20, 2004, $<$ http://proxy.library.carleton.ca:17814/intranet/cgi/presents?STYLE=739318018 \&PRESENT=DB=985,AN=197251271,FM=9,SEARCH=MD.Generic Search $>$ (cited November, 2004). 
Kolhatkar, Sonali, "Afghan Women Continue to Fend For Themselves," Foreign Policy in Focus Report; Interhemispheric Resource Center; Silver City, NM; March 2004.

Lepard, Brian D. Rethinking Humanitarian Intervention; A Fresh Legal Approach Based on Fundamental Ethical Principles in International Law and World Religions, Pennsylvania State University Press; University Park, Pennsylvania; 2002.

Lister, Sarah \& Andrew Wilder, "Strengthening Subnational Administration in Afghanistan: Technical Reform or State-Building?" in Public Administration and Development, Vol. 25, pp. 39-48, 2005.

Lieven, Anatol, "Don't Forget Afghanistan," Carnegie Endowment, updated 2005 ,

$<\mathrm{http}: /$ www.carnegieendowment.org/npp/publications/index.cfm?fa $=$ view\&id=9 102> (cited August, 2005).

Luckham, Robin, Anne Marie Goetz \& Mary Kaldor, "Democratic Institutions and Democratic Politics," in Can Democracy Be Designed? The Politics of Institutional Choice in Conflict Torn Societies, Sunil Bastian \& Robin Luckham Editors, Zed Books; New York \& London; 2003, pp. 14-59.

Magnus, Ralph H. \& Eden Namby, Afghanistan; Mullah, Marx, and Mujahid. Westview Press; Boulder, Colorado; 1998.

Marks, Susan, The Riddle of all Constitutions; International Law, Democracy and the Critique of Ideology, Oxford University Press; New York, New York; 2000.

Marsden, Peter, "Afghanistan: the reconstruction process," in International Affairs, Vol. 79, Issue 1, pp. 91-105, 2003.

Massoud, Waheedulla, "Afghanistan's Women Candidates Brave Threats," Afghan News Network, updated September 14, 2005, $<$ http://afghannews.net/printer.php?action=show\&type=news\&id=3327> (cited September 15, 2005).

McFaul, Michael, "Democracy Promotion as a World Value," in The Washington Quarterly, Vol. 28, No. 1, pp. 147-163, 2004-2005.

Mertus, Julie A. "The Undermining of Human Rights Culture in Kosovo," in Carnegie Council on Ethics and International Affairs Human Rights Dialogue, Series 2, No. 5, pp 8- 9, Winter, 2001. 
Monshipouri, Mahmood, "NGO's and Peacebuilding in Afghanistan," in Mitigating Conflict, February, pp. 138-155, 2003.

Montgomery, John D. \& Dennis A. Rondinelli editors, Beyond Reconstruction in Afghanistan; Lessons from Development Experience, Palgrave MacMillan; New York, New York; 2004.

Morarjee, Rachel, "Karzai Faces Battle to Tame Afghan Parliament," Afghan News Network, updated September 14, 2005, $<$ http://afghannews.net/printer.php?action=show\&type=news\&id=3326> (cited September 15, 2005).

Mutua, Makau, "Savages, Victims and Saviors: The Metaphor of Human Rights," in Harvard International Law Journal, Vol. 42, Winter, 2001.

NATO "NATO in Afghanistan; Fact Sheet" updated 2004, $<$ http://www.nato.int/issues/afghanistan> (cited February, 2005).

Nathan, Joanna \& Mark Schneider, "Will U.S. Abandon Afghanistan?" (The Washington Times) Afghan News Compiled by the Embassy of Afghanistan in Canada, updated September 18, 2005, <www.afghanemb-canada.net> (cited September 19, 2005).

Neuwirth, Jessica, "Women and Peace and Security: The Implementation of U.N. Security Council Resolution 1325," in Duke Journal of Gender Law and Policy, Vol. 9, Summer, 2002.

Newton, James, "Post-Conflict Institutions That Promote Human Rights: The Human Rights Chamber for Bosnia and Herzegovina," in Carnegie Council on Ethics and International Affairs Human Rights Dialogue, Series 2, No.5, pp. 1416, Winter, 2001.

Nicol-Wilson, Merlon \& Nadia Wassef, "Ending Female Genital Mutilation without Human Rights: Two Approaches," in Carnegie Council on Ethics and International Affairs Human Rights Dialogue, Series 2, No. 3, pp. 8-10, Summer, 2000.

Nolan, Robert, "NATO: A New Role in the Greater Middle East?" Foreign Policy Association: Global Views, updated July 1, 2004, $<$ http://www.fpa.org/newsletter_info2583/newsletter_info_sub_list.htm> (cited November 5, 2004).

Nussbaum, Martha, "The 'Capabilities' Advantage to Promoting Women's Human Rights," in Carnegie Council on Ethics and International Affairs Human Rights Dialogue, Series 2, No. 3, pp. 10-13, Summer, 2000. 
Orford, Anne, "Feminism, Imperialism and the Mission of International Law," in Nordic Journal of International Law, Vol. 71 pp. 275-296, 2002.

Orford, Anne, Reading Humanitarian Intervention; Human Rights and the Use of Force in International Law, Cambridge University Press; Cambridge, United Kingdom; 2003.

Othman, Norani, "Grounding Human Rights Arguments in Non-Western Culture: Shari'a and the Citizenship Rights of Women in a Modern Islamic State," in The East Asian Challenge for Human Rights, Joanne Bauer \& Daniel A. Bell editors, Cambridge University Press; Cambridge, United Kingdom; 1999.

Ottaway, Marina, "Nation Building," in Foreign Policy, Issue 132, pp. 16-23, Sept/Oct 2002.

Ottaway, Marina \& Bethany Lacina, "International Interventions and Imperialism: Lessons from the 1990's," in SAIS Review, Vol. 23, No. 2, pp 71-92, 2003.

Otto, Dianne, "Nongovernmental Organizations in the United Nations System: The Emerging Role of International Civil Society," in Human Rights Quarterly; Vol. 18, No. 1, 107-141, 1996.

Packer, George, "Dreaming of Democracy," in the New York Times Magazine, March 2, 2003, p. 44.

Patrick, Stewart, "The Check is in the Mail: Improving Delivery and Coordiantion of Postconflict Assistance," in Global Governance, Vol. 6, Issue 1, pp. 61-95, 2000.

Pazira, Nelofer, "Image and Reality: Women in Afghanistan," Public Lecture at Carleton University, Ottawa; October, 29, 2003.

Pazira, Nelofer, Book Launch and Reading of A Bed of Red Flowers: In Search of My Afghanistan, (Random House Canada; Toronto, 2005) Ottawa, April, 2005.

Peake, Gordon, "From Warlords to Peacelords?" in Journal of International Affairs Vol. 56, No. 2, pp. 181-191, Spring, 2003.

Pei, Minxin \& Sara Kasper, "Lessons from the Past: the American Record on Nation Building," Carnegie Endowment for International Peace Policy Brief, updated May, 2003, <www.ceip.org/pubs> (cited November, 2005)

Perritt, Henry H. Jr. "Iraq and the Future of the United States Foreign Policy: Failures of Legitimacy," in Syracuse Journal of International Law and Commerce, Vol. 31, Summer, 2004. 
Press Secretary, Office of, "Joint Statement Between the United States of America and Afghanistan," updated February 27, 2003, $<$ http://www.state.gov/p/sa/rls/pr/18097.htm> (cited November, 2004)

Prosper, Pierre-Richard, "Symposium: Reluctant Nation Building: Securing the Rule of Law in Post-Taliban Afghanistan: on Respect for the Rule of Law," in Connecticut Journal of International Law, Vol. 17, pp. 433-436, 2002.

Radio Free Europe / Radio Liberty, "Experts Voice Concern Over 2005 Afghan Parlimentary Elections," updated October 28, 2004, $<$ http://www.globalpolicy.org/security/issues/afghan/2004/1028concern.htm> (cited September 12, 2005).

Rahman, Maseeh, "Afghan Election Ends in Crisis," updated October 10, 2004, $<$ http://www.mideast.ru/new/index/php> (cited November, 2004).

Rasanayagam, Angelo, Afghanistan: A Modern History; Monarchy, Despotism or Democracy? The Problems of Governance in the Muslim Tradition, I.B. Tauris \& Co. Ltd.; New York, New York; 2003.

Rashid, Ahmed, "Afghanistan Faces Uncertainty After its Landmark Vote," Eurasia Insight, updated September 16, 2005, $<\mathrm{http}: / /$ www.eurasianet.org/departments/insight/articles $>$ (cited September 20, 2005).

Rawi, Miriam, "Rule of the Rapists; Britain and the US said war on Afghanistan would liberate women. We are still waiting," In The Guardian UK Newspaper, Thursday, February 12, 2004.

Riphenburg, Carol J. "Ethnicity and Civil Society in Contemporary Afghanistan," in Middle East Journal, Vol. 59, Issue 1, pp. 31-51 2005.

Roberts, Jeffery J. The Origins of Conflict in Afghanistan, Praeger; Westport, CT; 2003.

Rodgers, Jayne, "Bosnia and Kosovo: Interpreting the Gender Dimensions of International Intervention," in Dimensions of Western Military Intervention Colin McInnes and Nicholas J. Wheeler Editors, Frank Cass Publishers. Portland, Oregon; 2002, pp. 183-195.

Rodman, Peter, W. "United States Security Policy in Afghanistan on the Eve of National Elections," Committee on International Relations; U.S. House of Representatives, Washington, D.C. updated September 23, 2004, $<$ http://wwwa.house.gov/internatioanl_relations/108/rod092304.htm> (cited July, 2005). 
Rubin, Barnett R. "Transitional justice and human rights in Afghanistan," in International Affairs, Vol. 79. Issue 3, pp. 567-581, 2003.

Rubin, Barnett R. "(Re)Building Afghanistan: The Folly of Stateless Democracy," in Current History, Vol. 103, No. 672, pp. 165-170, April, 2004.

Rubin, Barnett R. "Afghanistan: The wrong voting system," in the International Herald Tribune, Wednesday, March 16, 2005.

Rubin, Elizabeth, "Women's Work; Now that female candidates have a secured place in the new Afghan Parliament, can they transform their country's politics, culture - and men?" in the New York Times Magazine, October 9, 2005.

Said, Edward W. Orientalism, Vintage Books; New York, New York; 1979.

Said, Edward, "A Window on the World," in the Guardian Newspaper, August 2, 2003.

Saikal, Fazel Haq, Modern Afghanistan: A History of Struggle and Survival, I. B. Tauris; London \& New York, 2004.

Sardar, Ziauddin, Orientalism; Concepts in Social Sciences, Open University Press; Philadelphia, PA; 1999.

Schetter, Conrad, "Ethnoscapes, National Territorialisation, and the Afghan War," in Geopolitics, Vol. 10, pp. 50-75, 2005.

Scheuerman, William E. "Cosmopolitan Democracy and the Rule of Law," in Ratio Juris, Vol. 15 No. 4, pp. 439-457, December, 2002.

Schofield, Victoria, Afghan Frontier: Feuding and Fighting in Central Asia, Tauris Parke Paperbacks; London \& New York; 2003.

Sedra, Mark, "Afghanistan: Democracy Before Peace?" Silver City, NM \& Washington, DC: Foreign Policy in Focus, September, 2004.

Sedra, Mark \& Peter Middlebrook, "Beyond Bonn; Revising the International Compact for Afghanistan" Foreign Policy In Focus Special Report November 2, 2005, <http://www.fpif.org/fpiftxt/2912> (cited November 15, 2005).

Seierstad, Asne The Bookseller of Kabul, Virago; London, Great Brittan; 2002.

Sengupta, Somini, "Violence Continues in Afghanisran Ahead of Election," New York Times, updated September 16, 2005, $<$ http://www.nytimes.com/2005/09/16/international/asia/16cnd-afghan.html > (cited September 20, 2005). 
Shah, Amir, "Afghans Go To The Poles," The Globe and Mail, updated September 18, 2005,

$<$ http://www.thegolbeandmail.com/servlet/story/RTGAM.20050917.wafghan091

7/BNStory/International $>$ (cited September 24, 2005).

Shah, Niaz A. "The Constitution of Afghanistan and Women's Rights," in Feminist Legal Studies, Vol. 13, pp. 239-258, 2005.

Shaw, Malcom N. International Law; Fifth Edition, Cambridge University Press; Cambridge, United Kingdom; 2003.

Shelby, David, "Afghans Prepare To Elect First Parliament in Decades," (Washington File Staff Writer) updated August 26, 2005, $<$ http://usinfo.state.gov/sa/Archive/2005/Aug/26-699048.htm> (cited September $15,2005)$.

Shelby, David, "Afghan Women Compete for Seats in National, Provincial Legislatures," (Washington File Staff Writer) updated August 26, 2005, $<$ http://usinfo.state.gov/sa/Archive/2005/Aug/26-201799.htm> (cited September $15,2005)$.

Smith, Graeme, "Ballots, Bribes and Bullets, Watchdogs and Warlords," The Globe and Mail, updated September 17, 2005, $<$ http://www.theglobeandmail.com/servlet/ArticleNews/TPStory/LAC/20050917/ AFGHANISTAN17> (cited September 24, 2005).

Smith, Graeme, "In Afghanistan, Women Know Their Place - In Parliament," The Globe and Mail, updated September 20, 2005, $<$ http://www.theglobeandmail.com/servlet/ArticleNews/TPStory/LAC/20050920/ AFGHANWOMEN20> (cited September 24, 2005).

Smith, Graeme, "Afghans May Vote In The Communists They Drove Out; Nostalgia For The Years After The Soviet Invasion Leads To Unlikely Choices," The Globe and Mail, updated September 22, 2005, <http://www.thegolbeand mail.com/servlet/ArticleNews/TPStory/LAC/20050922/AFGHAN22/TPInternatio nal> (cited September 24, 2005).

Stanley Foundation (The), "Who Rebuilds After Conflict?; $38^{\text {th }}$ Conference on the United Nations of the Next Decade," June $15^{\text {th }}$ to $20^{\text {th }}, 2003$.

Steans, Jill, "Global Governance: A Feminist Perspective," in The Global Transformation Reader; an Introduction to the Globalization Debate, $2^{\text {nd }} \mathrm{ed}$. David Held \& Anthony McGrew Editors, Polity Press; Cambridge, UK; 2003, pp. 87-108. 
Stockman, Farah, "Afghan Women Take Special Joy in Vote," (Boston Globe) Afghan News Compiled by the Embassy of Afghanistan in Canada, updated September 20, 2005, <www.afghanemb-canada.net> (cited September 21, 2005).

Stockton, Nicholas, "Afghanistan, War, Aid and International Order," in Nation Building Unraveled? Aid, Peace and Justice in Afghanistan. Antonio Donini, Norah Niland \& Karin Wermester Editors, Kumarian Press; Connecticut; 2004, pp. 9-36.

Suhrke, Astri, Kristian Berg Harpviken \& Arne Strand, "After Bonn; Conflictual Peace Building," in Third World Quarterly, Vol. 23, No. 5, pp. 875-891, 2002.

Synovitz, Ron, “Afghanistan: NATO Looks To Expand Mission After September Elections," Radio Free Europe / Radio Liberty, updated September 1, 2005 $<$ http://www.rferl.org/featuresarticleprint/2005/09/b9833987-682a-4f2a-a1d0ed5f544c2af4> (cited September 15, 2005).

Synovitz, Ron, "Elections Officials Again Delay Certification of Results" updated November 9, 2005, $<$ http://www.rferl.org/en/specials/elections/features/archives/2005/11.asp > (cited November 26, 2005).

Taft, William H. "Address of Legal Advisor William H. Taft, IV to the International Bar Association Regarding the U.S. and Global Response to the Threat of International Terrorism," updated September 18, 2003, $<$ http://www.state.gov/s/1/2003/44395.htm> (cited November, 2004).

Tarzai, Amin, "New Parliament Must Cope With Deep Divisions" updated November 18, 2005, $<$ http://www.rferl.org/en/specials/elections/features/archives/2005/11.asp > (cited November 26, 2005).

Tempest, Matthew and agencies, "Interrogators 'Lacked Rights Training'," in The Guardian, U.K., March 10, 2005.

Teson, Fernando R. Humanitarian Intervention: An Inquiry into Law and Morality; Second Edition, Transnational Publishers, Inc.; New York, USA; 1997.

Their, Alexander \& Jarat Chopra, "The Road Ahead: Political and Institutional Reconstruction in Afghanistan," in Third World Quarterly, Vol. 23, No. 5, pp. 893-907, 2002.

Thrupkaew, Noy, “Afghanistan Update; U.S. Policy Is Shortchanging Afghan Women," Ms. Magazine, updated September, 2003, $<$ http://www.msmagazine/sept03/thrupkaew/asp> (cited November, 2004). 
Travis, Hannibal, "Freedom or Theocracy?: Constitutionalism in Afghanistan and Iraq," in Northwestern University Journal of International Human Rights, Vol. 3, Spring, 2005.

US Agency for International Development, $<$ http://www.usaid/gov/locations/asia_near_east/afghanistan/> (cited November 2004).

US Bureau of South Asian Affairs, "Background Note: Afghanistan" updated April, 2005, <http://www.state.gov/r/pa/ei/bgn/5380.htm> (cited April 22, 2005).

U.S. Department of State, "Fact Sheet: Progress in Afghanistan," updated March 24, 2003, <http://www.state.gov/p/sa/rls/fs/18939pf.htm> (cited November 16, 2004).

United Nations Assistance Mission to Afghanistan, (UNAMA), $<\mathrm{http}: / /$ www.unama-afg.org/docs/UN-Docs.htm> (cited February 17, 2005).

United Nations Development Programme, $<\mathrm{http}: / /$ democraticdialoguenetwork.org/english/glossary/content/viewone?term_id=4357> (cited December 2, 2005).

United Nations Millennium Project, "UN Millennium Project" $<$ http://www.unmillenniumproject.org/who/index.htm> (cited March 26, 2005).

United States General Accounting Office, "Afghanistan Reconstruction: Deteriorating Security and Limited Resources Have Impeded Progress; Improvements in the U.S. Strategy Needed," updated June, 2004, $<$ www.gao.gov/cgi-bin/getrpt?GAO-04-403> (cited December, 2004).

Universal Declaration of Human Rights, 1948, $<$ www.un.org/rights/50/decla.htm> (cited January, 2005).

Verdirame, Guglielmo, "Testing the Effectiveness of International Norms: UN Humanitarian Assistance and Sexual Apartheid in Afghanistan," in Human Rights Quarterly, Vol. 23, No. 3, pp. 733-768, 2001.

Voigt, Stefan, "Islam and the Institutions of a Free Society," in the Independent Review, Vol. X, No. 1, pp. 59-82, 2005.

Von Hippel, Karin, "Democracy by Force: a Renewed Commitment to Nation Building," in The Washington Quarterly, Vol. 23, No. 1, pp. 95-112, 2000.

Wardak, Ali, "Building a Post-War Justice System in Afghanistan," in Crime, Law and Social Change; Vol. 41, 319-341, 2004. 
Watson, Patrick \& Benjamin R. Barber, The Struggle for Democracy, Key Porter Books Ltd. Toronto, Canada, 2000.

Whitworth, Sandra, Men Militarism \& UN Peacekeeping: A Gendered Analysis, Lynne Riener Publishers Inc; Boulder, Colorado; 2004.

Wilde, Ralph, "From Danzing to East Timor and Beyond: the Role of International Territorial Administration," in the American Journal of International Law, Vol. 95, pp. 583-605, 2001.

Wimmer, Andreas \& Conrad Schetter, "Putting State Formation First: Some Reccomendations for Reconstruction and Peace-Making in Afghanistan," in Journal of International Development; Vol. 15, 525-539, 2003.

Wings Over Afghanistan, Discovery Channel Documentary, distributed by Magna Pacific, 2002.

Wippman, David, "Nation Building Lessons from the Past and the Challenges Ahead: Power Sharing in Iraq," in New England Law Review, Vol. 39, Fall, 2004.

Wood, William B. "Bolstering Democracy in Iraq, Afghanistan and Kyrgyzstan: Post-Conflict Intervention Revisited: Relief, Reconstruction, Rehabilitation and Reform," in The Fletcher Forum of World Affairs Journal, Vol. 29, Winter, 2005.

World Press Review, "Just the Basic Rudiments; The Bonn Accord," Vol. 49, No. 2, 2002, updated February, 2002, $<$ http://www.worldpress.org/asia/0202thenews.htm> (cited November, 2004).

Yusufzai, Rahimullah, "Taliban claim 51 attacks launched" (The News International, Pakistan) Afghan News Compiled by the Embassy of Afghanistan in Canada, updated September 20, 2005, <www.afghanemb-canada.net> (cited September 21, 2005). 